DOI 10.21685/2500-0578-2020-3-4

\title{
DANGEROUS GIANTS? - LARGE HERBIVORES, FOREST FEEDBACKS AND CLIMATE TIPPING POINTS
}

\section{Sheil}

Norwegian University of Life Sciences (NMBU), Ås, Norway

E-mail: douglas.sheil@nmbu.no

Abstract. Could large herbivores ("megaherbivores") modify tree-cover sufficiently to disrupt the hydrological cycle? The implications of such interactions are profound: potentially switching climates from wet to arid. Was such instability important in the past? Here, inspired by the suggestions of Gorshkov and Makarieva [1], I review the influence of megaherbivores on forests and examine what we can learn from the largest modern example, the Bush elephant (Loxodonta africana Blumenbach). These animals can certainly reduce tree and forest cover, but some tree species appear able to repel, resist or even tolerate them. Furthermore, elephant populations are vulnerable to dehydration, starvation, disease, and predation, and are thus not immune to environmental change and feedbacks. I look at the dynamics of tropical tree cover, and the balance with tropical savannas. I find evidence that megaherbivores can influence tree cover over extensive regions and might, in suitable circumstances, help tip the climate from wet to dry if such a tipping point was close. But the overall story remains complex and human influences obscure our view of key processes. While there are good reasons to believe that megaherbivores could be influential, we neither know nor fully understand the processes that led to past expansion and maintenance of savanna and other firemaintained biomes. The role of fire and flammable biomes, and the factors - including animals - that may influence them, require more attention. Fire has an appetite considerably larger than that of any megaherbivore. points.

Key words: disturbance-ecology, elephants, fire, forest-dynamics, Loxodonta, megafauna, savanna, tipping

Acknowledgements. I am honoured to offer this commentary and hope I have done these ideas justice. If only we could discuss them with Victor Gorshkov, I am sure we would go further. His imaginative insights, analyses and humour will be missed. I thank Anastasia Makarieva for inviting this commentary and Alexei Aleinikov for editorial guidance. Badru Mugerwa kindly provided the images for figure one. I also thank Anastasia Makarieva, Stein Moe, Richard Bischof, Miriam van Heist, Ryan Burner, Yennie Katarina Bredin, Joseph Hawes, Larisa Khanina and an anonymous reviewer for helpful feedback, including important clarifications and suggestions, on earlier drafts.

For citation: Sheil D. Dangerous giants? - Large herbivores, forest feedbacks and climate tipping points. Russian Journal of Ecosystem Ecology. 2020;5(3). Available from: https://doi.org/10.21685/2500-0578-2020-3-4

УДК $573 * 57.07 * 581 * 591.5$

\section{ОПАСНЫЕ ГИГАНТЫ? - КРУПНЫЕ РАСТИТЕЛЬНОЯАНЫЕ ЖИВОТНЫЕ, РЕАКЦИЯ ЛЕСА И КРИТИЧЕСКИЕ КЛИМАТИЧЕСКИЕ СОСТОЯНИЯ}

\section{А. Шейл}

Норвежский университет естественных наук (NMBU), г. Ос, Норвегия

E-mail: douglas.sheil@nmbu.no

Аннотация. Могли бы крупные растительноядные животные (“megaherbivores”) модифицировать древесный покров до такой степени, чтобы разрушить круговорот воды? Последствия таких действий значительны, вплоть до изменения климата от влажного к засушливому. Играла ли эта неустойчивость существенную роль в прошлом? В этой статье, принимая во внимание предположения работы Горшкова и Макарьевой [1], приводится обзор воздействия крупнейших растительноядных животных на лес с более подробным рассмотрением на примере наиболее крупного из существующих растительноядных - саванного слона (Loxodonta africana Blumenbach). Эти животные, несомненно, могут существенно уменьшать древесный и лесной покров, но некоторые виды деревьев, как представляется, способны противостоять слонам, выдерживать их воздействие или даже сосуществовать с ними. Более того, сами слоны подвержены воздействию хищников, обезвоживанию, голоду и болезням, а потому не защищены от изменений окружающей среды. Рассматривается динамика тропического лесного покрова и его баланс с тропическими саваннами. Представлены данные о том, что крупнейшие растительноядные животные действительно могут свести лесной покров на нет на значительных площадях и могли в соответствующих условиях подтолкнуть климат к переходу из влажного в сухое состояние, если такая критическая точка была достаточно близка. Но в целом проблема остаётся 
сложной, и воздействие человека препятствует ясному пониманию ключевых процессов. Хотя есть достаточные основания считать, что крупнейшие растительноядные могли оказывать на экосистемы большое влияние, мы не знаем и полностью не понимаем те процессы, которые в прошлом привели к распространению и поддержанию саванны и других биомов, зависящих от пожаров. Роль пожаров и подверженных горению биомов, а также факторов (включая и животных), которые на них влияют, заслуживает большего внимания. “Аппетит” у пожара существенно превосходит таковой у любого из крупнейших растительноядных животных.

Ключевые слова: экология возмущений, слоны, пожар, лесная динамика, Loxodonta, мегафауна, саванна, критические точки.

Благодарности. Для меня большая честь выступить с этим комментарием, и я надеюсь, что я воздал должное этим идеям. Если бы мы только могли обсудить их с Виктором Горшковым, я уверен, что мы продвинулись бы дальше. Его творческих идей, анализа и юмора будет не хватать. Я благодарю Анастасию Макарьеву за приглашение к этому комментарию и Алексея Алейникова за редакционные рекомендации. Бадру Мугерва любезно предоставил изображения для первого рисунка. Я также благодарю Анастасию Макарьеву, Штайн Мо, Ричарда Бишофа, Мириам ван Хейст, Райана Бёрнера, Йенни Катарину Бредин, Джозефа Хауза, Ларису Ханину и анонимного рецензента за полезные отзывы, включая важные пояснения и предложения, к более ранним версиям статьи.

\section{Preamble}

Gorshkov and Makarieva [1] weave together multiple themes - including energy flows, metabolic processes, geometric limits and powerful climatic feedbacks - to suggest that large animals can reach densities that remove sufficient tree cover to "claim all ecosystem productivity" and undermine climatic stability. To investigate these suggestions, I examine large herbivores ("megaherbivores") and the stability of forests and other tree cover. Though crucial, I shall not explore the influence of tree cover on rainfall as this is a subject I have discussed and summarised in detail elsewhere [2]. In brief, the proposal is that largescale tree cover sustains rainfall within continents through powerful positive feedbacks and loss of tree cover reduces these feedbacks and can result in a catastrophic switch of states where wellwatered regions become arid. My focus here is on what we know or might infer about the impacts of large animals on tree cover with a focus on examples I am familiar with: Bush elephants and tropical vegetation. While, as a field ecologist, I often take a detail-oriented approach, I appreciate how elegant theoretical reasoning encourages us to look further and deeper.

I have organised this commentary by sections summarising evidence, theory and unknowns around selected themes pertinent to the larger puzzle. The Giants overviews megaherbivores both past and present. Elephants and Tree Mortality summarises the direct impacts of elephants on trees and tree cover. Population Growth and Constraints asks what factors can, or might, govern elephant populations. Savannas in an Evolutionary Context explores how modern savannas arose and how both fire and herbivory influenced the evolution of these biomes. Savanna-Forest Dynamics looks more closely at the processes governing savannas and tree cover with an emphasis on fire. Animal Influences notes the complexity of understanding outcomes that depend upon multiple processes, including animals. Conservation Comments clarifies the interpretation of the ecological role of mega- herbivores. In the final section, Synthesis, I combine the puzzle pieces to reveal the overall picture.

\section{The giants}

Our world has lost many giants. There is considerable uncertainty on size estimates [3] but the largest ever terrestrial animals were likely the long-necked dinosaurs such as South America's $\sim 73$ tonne Argentinosaurus huincluensis (Bonaparte \& Coria $^{1}$ ) and Africa's $~ 60$ tonne Paralititan stromeri (Smith et al.) [4]. Such sizes may have been an adaptation to feeding on trees, with an apparent correlation between the occurrence of longnecked sauropods and forest $[5,6]$. The largest terrestrial mammals were likely the extinct $\sim 16$ tonne Eurasian mammoth Zygolophodon borsoni (Hays) [7] or the extinct hornless rhinoceros Indricotherium transouralicum (Pavlova), that achieved 11 to 17 tonnes $[7,8]$.

Of the 42 terrestrial mammals surpassing one tonne that existed 20,000 years ago just eight remain [9, 10]. Several more giants, including Europe's hippopotamus species, e.g., Hippopotamus antiquus Desmarest, $H$. major Cuvier and $H$. gorgops Dietrich, were lost prior to this period too. The loss of such animals - many of which are judged to have been "ecosystem engineers" having a major impact on the biomes in which they occurred - has many potential implications for vegetation structure and composition in the biomes from which they departed $[11,12]$ (implications which I discuss in subsequent sections). We remain unsure about the typical sizes, behaviours, and distributions of many of these species as remains are sparse and often enigmatic. Isotopic data can estimate the fraction of $\mathrm{C} 4$ vegetation (mainly grasses) in paleo-diets [e.g., 13, 14]. Tooth morphology and wear can indicate other aspects of diet [e.g., 15], but we cannot be certain how animals impacted vegetation.

${ }^{1}$ I provide the accepted taxonomic name and authority (in brackets) at first mention. 
A few thousand years ago, animals in the order Proboscidea ("the proboscideans") occurred across all the continents except Australia and Antarctica. Eurasia's woolly mammoth (Mammuthus primigenius Blumenbach) achieved seven or eight tonnes and became extinct only around four thousand years ago [16], while North America's M. columbi (Falconer) spp. surpassed ten tonnes [7], the Asian Stegodon zdanskyi (Hopwood) exceeded twelve tonnes and some of South America's Gomphotheriidae (e.g., Cuvieronius spp.) exceeded four [4]. All these likely included some browse in their diets [e.g., 14, 17]. The Elephantidae, the only surviving family of the order, arose in Africa within the last ten million years. These included not only the extinct mammoths but also Europe's straight tusked elephants Palaeoloxodon antiquus (Falconer \& Cautley) that reached 15 tonnes, and were extinct thirty-thousand years ago [18]. Genetic data show that the latter were most closely related to Africa's extant (and smaller) Forest elephants (Loxodonta cyclotis Matschie $)^{2}$ [19]. Investigations suggest all these animals grazed and browsed, including coarse woody materials in their diets [20].

Proboscideans are not the only giants we lost. For example, the Woolly rhinoceros (Coelodonta antiquitatis Bronn) reached two tonnes or more and was common throughout Europe and northern Asia before going extinct around 10,000 years ago [21]. Isotopic analysis of horn proteins suggests a seasonal diet with summer grazing and winter browsing [22]. Other European megafauna included several hippopotamuses, and the cave bears (Ursus spelaeus Rosenmüller), which occasionally reached one tonne in size - though likely opportunistic omnivores, these bears appear to have been primarily herbivorous $[23,24]$. In the neotropics the ground sloths included several large species, such as Megatherium americanum (Cuvier) that reached four tonnes [25] and browsed [15, 26]. In Australia, the wombat-like Diprotodon optatum (Owen), a part-time browser, reached over two and a half tonnes $[27,28]$. The list could continue.

Modern day ecology is an imperfect guide to the past: people and domestic animals have impacted much of the planet. The biomass of domestic animals now exceeds that of modern wild mammals and likely surpasses what was present in the Pleistocene [29]. Aside from the forest cleared for ranching, the replacement of native wildlife with livestock has likely had many more subtle impacts. For example, it has likely contributed to the widespread increase in tree cover in some parts of tropical Africa [30]. Where megaherbivores persist, their distributions, densities, movements, and behaviours are seldom free of human impacts.

2 This appears to invalidate the genus Loxodonta, though an accepted resolution has yet to be found at the time of writing.
The three largest surviving species of terrestrial megafauna are the elephants. The Bush elephant (Loxodonta africana Blumenbach, 1797) and the smaller Forest elephant (L. cyclotis) are restricted to continental Africa and were considered subspecies until recently $[31,32]$ but the genetic evidence for separation is unambiguous [33-35] and shows no significant interbreeding in the last half million years [19]. Both sexes of both species grow throughout their lives [7]. Adult bull Bush elephants can exceed six tonnes, with some accounts claiming over ten, while Forest elephants seldom exceed 3.5 tonnes [7]. The third species is the Asian elephant (Elephas maximus Linnaeus, 1758) which seldom reaches five tonnes [7].

Here, I shall focus on the African elephants. Both species have been heavily hunted - impacting their distributions, densities and behaviours [36, 37]. Despite these caveats, as Hempson and colleagues note [30], "Africa is effectively the world's last laboratory for testing the effects of native large mammal herbivores on ecosystems".

While the Bush elephant persists in scattered populations in a diversity of dry, seasonal and humid climates in sub-Saharan Africa, the Forest elephant has a more restricted distribution and occurs in a moist equatorial region including northern Congo, Gabon, the Central African Republic and southern Cameroon. Where they overlap the two species may mingle but seldom hybridise [38]. A frequent misunderstanding arises from the names of these animals, given that Bush elephants frequently use (and reside in) forests while Forest elephants often use, and spend considerable time in, non-forest habitats.

While all modern elephant species are generalised feeders - eating fruit, grasses, herbs and foliage when available - they are distinct from smaller browsers in their ability to utilise low quality fibrous and woody material too. This is consistent with theory which indicates that the largest animals can access and utilize foods that would be neither available nor nutritionally viable for smaller animals [39, 40]. Bush elephants (which are better studied) regularly consume bark, twigs and other woody material. These animals are also better able to gouge through thick bark, push down trees and dig up thick roots [41-43]. The proportion of woody material in their diet tends to be higher when alternatives are unavailable [42]. Woody material (primarily twigs and small branches ingested with foliage) can comprise over $90 \%$ of food intake of elephants during the dry season in the arid woodlands of the Chobe National Park, Botswana [44]. Similar selection patterns ( $80 \%$ woody material) have been seen in the dry season in wooded grassland of Tanzania's Ruaha National Park [45]. The ability to eat low quality foods does not mean 
elephants have low nutrient requirements or lack selectivity - rather they need to ingest nutrients at a greater rate than any other terrestrial mammal and choose the most nutritious foods they can [46]. Elephants derive sufficient nutrients from low quality foods only by consuming enormous quantities [47, 48]. Measured in dry matter, Bush elephants consume 1.0-1.6 percent of their body weight daily, while Asian elephants consume 1.5-1.9 percent [49]. Furthermore, while they ingest woody material, they do not seek wood, and wood alone lacks nutrients to sustain them. Indeed, while various organisms such as "white rot" Basidiomycota fungi, and several prokaryotes, metabolise and degrade lignin and lignocellulose, and this is also achieved by certain arthropods through microbial symbiosis $[50,51]$, we know of no vertebrates that derive significant energy from consuming wood.

\section{Elephants and tree mortality}

Gorshkov and Makarieva [1] are concerned with "megaherbivores", meaning herbivores that reach over one tonne. As noted above, few such species remain, and Bush elephants are the largest among them. So, do these elephants kill trees and clear forests?

Bush elephants do contribute to tree mortality and loss. Observations in a large but fenced South African savanna park with artificial watering points (Kruger) found treefalls were six times more frequent in areas used (versus unused) by elephants $[52,53]$. Long term studies show that these activities reduce tree cover (mean standing biomass declined by an estimated $87 \%$ between 1998 and
2012 as elephant numbers grew after culling ceased in 1994) [54]. In contrast, a similar increase in elephants in Chobe (also savanna) was not associated with reduced tree cover, though wetter years and changes in fire regime have been proposed as explanations [54-56]. In the Serengeti's equatorial savannas too, elephants contribute to tree mortality [57]. Various observations show that many trees are damaged or toppled without any feeding. Trees are sometimes pushed down in play or by an animal scratching itself (Fig. 2c). The reasons for this destructiveness remain unknown but social interactions appear to play a role [reviewed in 58].

In closed forests Bush elephants browse and trample saplings and seedlings (Fig. 1). They will often break the stems of small fruiting trees, such as Myrianthus holstii Engl., too [59]. Fredrick Ssali (my ex-student) followed $27 \mathrm{~km}$ of recent Bush elephant trails through the undergrowth of the Bwindi Impenetrable National Park (a mountain forest in Uganda). He found that the elephants knocked down $30.5 \%$ of the stems over $2 \mathrm{~cm}$ diameter within $2 \mathrm{~m}$ of their temporary trails, tore branches from $19 \%$ and stripped bark from 22 of 897 (mostly larger) tree stems [60]. Some pioneer species (the "weedier" trees that grow in disturbed areas) such as the fast growing Macaranga kilimandscharica Pax were preferred while some other species were avoided. Damage rates were greater for stems in or near more open versus denser forest [60]. Studies elsewhere also show that Bush elephants preferentially feed in more open and disturbed forest where there is typically more accessible vegetation $[61,62]$.
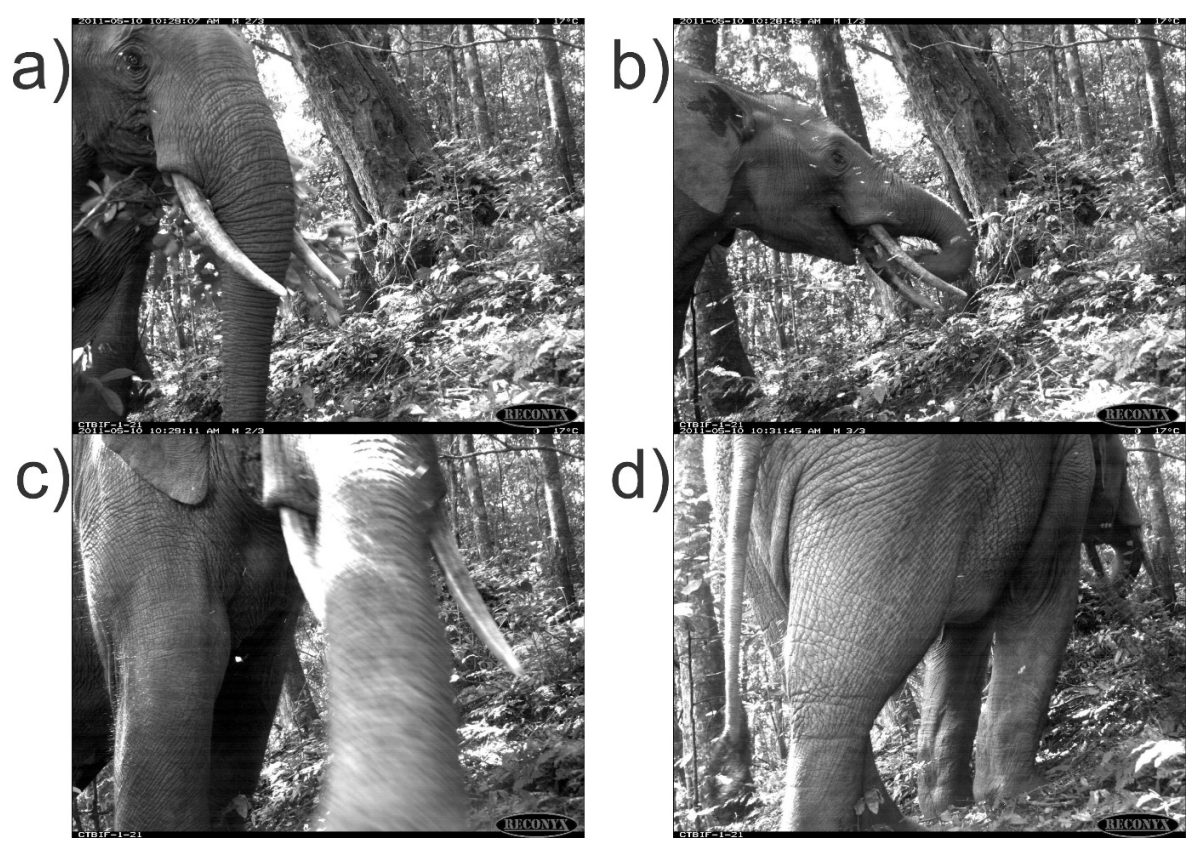

Fig. 1. Camera trap images, from the Bwindi Impenetrable National Park(Uganda) of an African Bush elephant

(Loxodonta africana). The animal (a) enters the frame and (b) feeds, before (c) turning to smell the camera, and $(d)$ continuing to feed on saplings. All photographs by B. Mugerwa and D. Sheil, TEAM Network 


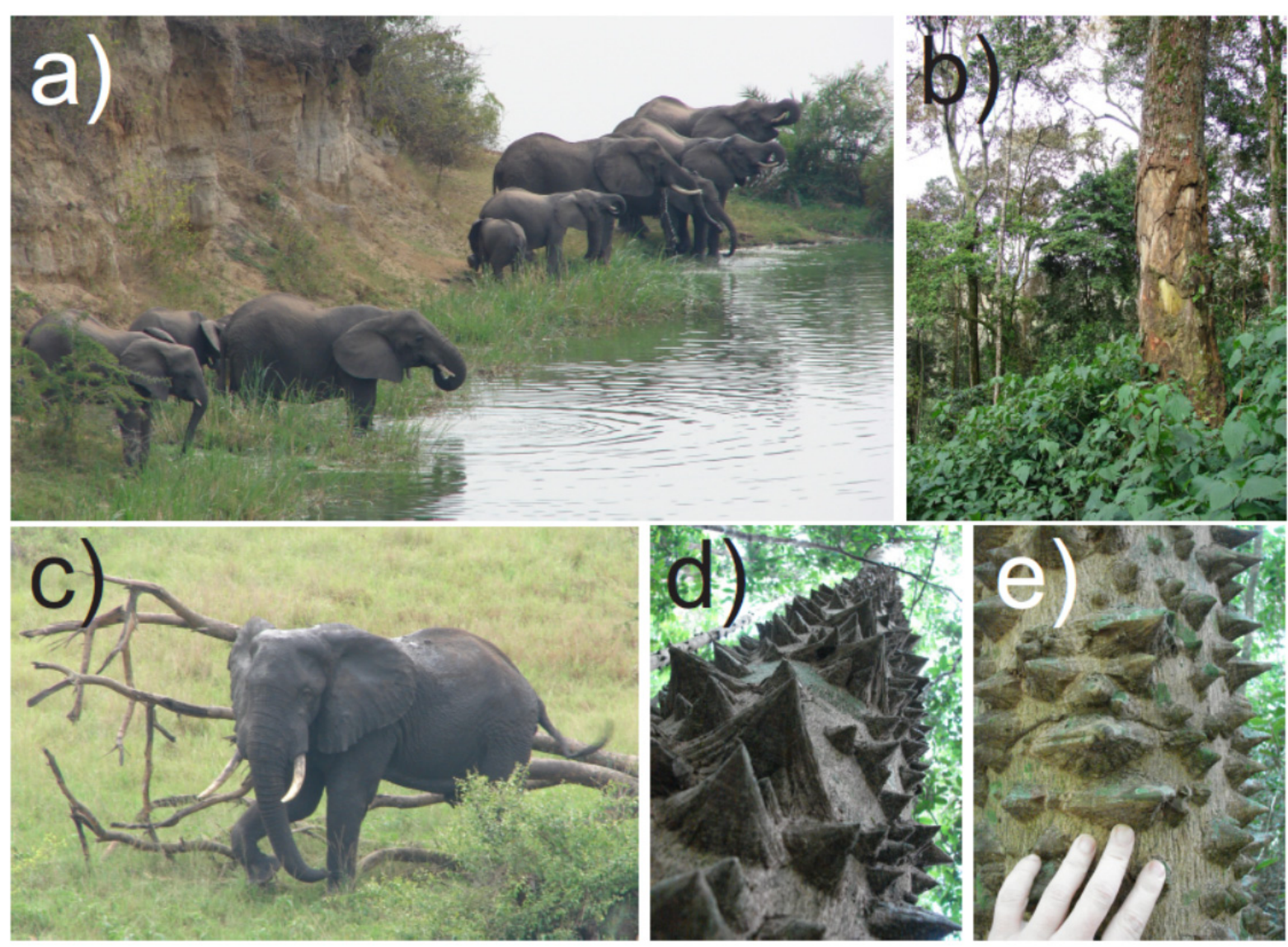

Fig. 2. $a$ - elephants depend on regular access to water and many of their impacts are greater near to favoured water access (here a heavily trampled access point in the Queen Elizabeth National Park, Uganda);

$b$ - a severely de-barked Symphonia globulifera L.f. tree in the Bwindi Impenetrable National Park (Uganda), withtusk marks visible up to 4 meters above the ground. Despite exuding a sticky yellow latex this species is often tusked; c - bush elephants often push down trees without feeding on them - here an animal is scratching itself against a fallen tree; $d, e$ - several forest tree species have stem structures that prevent elephants from peeling off their bark, here two Zanthoxylum L. (likely both Zanthoxylum gilletii (De Wild.) P. G. Waterman) in Uganda Zanthoxylum is a pantropical genus of about 200 species many of which bear similar structures on their stems. All photographs by D. Sheil

I have seen how Bush elephants damage large forest trees too - stripping bark and gouging stems (Fig. 2b). During my doctoral research in Uganda I found that most larger trees in the Rabongo Forest (a small remnant of old growth forest, regularly visited by Bush elephants from the surrounding Murchison Falls National Park) showed stem scarring from elephant tusks (more than half of stems over $50 \mathrm{~cm}$ diameter showed such damage) [63]. Ring-barking (removing bark all around the stem sometimes referred to as "girdling") generally kills an impacted tree while less severe bark damage increases the likelihood of rot and reduced life expectancy $[41,42,64,65]$. Though many animal species, including smaller taxa such as rabbits, voles, porcupines and beavers, along with deer and various primates, can cause such bark damage, and this causes significant local problems for forestry $[66,67]$, the wider ecological implications remain little studied. Indeed, I note that those who review causes of tree death in tropical forests generally neglect such influences [e.g., 68]. Nonetheless, such damage is clearly influential in many locations and was, like the megaherbivores, likely more widespread and consequential in the past.

In my studies in Uganda, I found evidence for four strategies - repellence, resistance, tolerance and avoidance - that help trees coexist with elephants [63]. For example, strong repellence is found in species which possess toxins in their sap or bark, such as Antiaris toxicaria Lesch., Strychnos mitis S.Moore and Erythrophleum suaveolens (Guill. \& Perr.) Brenan [63]. Repellence is also noted for Holoptelea grandis (Hutch.) Mildbr., a common forest edge species which emits a pungent "iodine like" smell when its bark is damaged [69 and DS pers. obs.]. All these species are left untouched by elephants [63]. Species with spiny stems such as Dichrostachys cinerea Wight \& Arn., and species with spine like structures such as Zanthoxylum gilletii (De Wild.) P. G. Waterman also seemed resistant to bark stripping and were seldom damaged [Fig. 2d,e, 63]. 
Some tree species appear to tolerate, or perhaps even benefit from, elephants. A good example comes from Kenya's Shimba Hills National Reserve, a coastal forest where a high density of Bush elephant has been seen to browse on fast growing Leptonychia usambarensis K. Schum. trees that coppice and maintain the forest in a thicket-like early successional state [70].

Elephants do not push down larger rain forest trees (over $20 \mathrm{~cm}$ diameter) and there would be little benefit in doing so. The main large forest tree in the forests I know, Cynometra alexandri C. H. Wright, remains largely untouched by elephants, though the animals occasionally gouge the lower parts of the stem and buttresses. They would not be able to bring the larger trees down. The wood is dense, extremely tough, and contains hard mineral crystals that quickly blunt steel saws. In my doctoral work I speculated that the abundance of buttressed stems and species in these forests resulted from selection by elephants: buttresses not only increase stem stability but reduced the risk of ring barking and of rot reaching the heartwood [for more details, see 63]. The main impacts appear to be through damage to smaller stems. A decline in elephants results in the understorey becoming denser due to reduced damage and is likely one reason why some African forests have been gaining biomass over the last half century [71-74].

The Forest elephant is less destructive than the Bush elephant. It tramples and browses but seldom tusks or topples trees $[75,76]$. Nonetheless, in forests used by these animals the density of saplings is negatively associated with local elephant densities [77]. They also, together with other large mammals, generate and maintain forest clearings called "baï" across Central Africa - through their feeding, trampling and digging $[78,79]$. The density of Forest elephants at, and around, forest edges is often higher, and sometimes much higher, than within the forest [76].

There are claims that Forest elephants ensure higher forest biomass than would otherwise occur. They supposedly favour large dense-timbered stems by selectively removing others with low density wood [80] - scepticism seems warranted, however, as the study neglects how these browsers favour and maintain open and disturbed vegetation, and results appear dependent on poorly justified model parameter values and the relationships among them. Relationships between timber densities and basal area in mixed species forests require further evaluation [suitable data exist, see, e.g., 81]. Others had long ago suggested that (Bush) elephants accelerate succession by preferentially impacting the regeneration of early successional species [82] (similar to the claim for Forest elephants noted above though neglected by them [80]). I have seen this preferential removal of early successional species in my own observations too, but the implications are context specific; elephants can favour both late and early successional species and thus generate and maintain heterogeneity [63]. The consequences of their feeding favour early successional species when they feed preferentially in and create more open areas and keep them open thus encouraging and maintaining rapid growing light demanding species - as in the Shimba Hills example mentioned above [70]. However, they also favour late successional species when they seek out and preferentially reduce more palatable species in the shadier environments where the remaining less palatable species maintain sufficient shade to prevent regeneration of pioneer species. Indeed, given the life-histories available to evolving tree species, I have speculated that in the presence of elephants it appears better for a tree species to specialise in being either a damagetolerant fast-growing pioneer or a repellent slowgrowing but well-defended late successional species - both of which can be favoured in suitable conditions - rather than a generalist that is poor at both and is less able to persist. Similar trade-offs, selecting for alternative specialisations, have been indicated in other studies of plant defence with relation to herbaceous plants and insects [e.g., 83, 84]. The presence of such pressures against generalist behaviours by trees suggests not only that mid-successional species are especially vulnerable to elephants and other large herbivores, but that such herbivores have accentuated the evolved differences between pioneer and shade-tolerant tree species [63]. One testable implication is that midsuccessional tree species will be less favoured when these animals are abundant than when they are scarce or absent [63].

So, elephants do kill trees. Bush elephants, in particular, are not limited by their appetites and often push down and damage trees without feeding. They have a major impact on savanna trees and modify the composition and structure of dense forests. Nonetheless, in the short term, not all tree species are vulnerable. Sustained trampling and damage could, over decades, prevent regeneration leading to larger trees not being replaced when they die (possibly aided by fire - see below). It would only be after this process was complete that elephants might "claim all ecosystem productivity" as Gorshkov and Makarieva [1] propose.

\section{Population growth and constraints}

Gorshkov and Makarieva [1] argue that megafauna lack the constraints on population growth 
that govern smaller fauna. Curiously, Darwin also wrote about the geometric growth of elephant populations in The Origin of Species: he noted there "is no exception to the rule that every organic being naturally increases at so high a rate, that if not destroyed, the earth would soon be covered by the progeny of a single pair" [p. 64, 85]. This theme was widely repeated [see 86]. Such examples highlight the hypothetical power of unlimited growth but reality differs.

Long-term studies have clarified the demography of elephants. Details vary with circumstances, but maximum population growth for Bush elephants has been estimated at around $7 \%$ per year: doubling each decade in productive open habitats [87-89]. Demographic rates for Forest elephants appear lower though researchers have avoided offering an estimate due to challenges in interpreting their observations [90]. Even if $7 \%$ per year is possible, can such growth rates be sustained? In nature we expect populations to approach some approximate equilibrium in which mortality and recruitment balance. So, what determines this balance for elephants?

The circumstances under which Bush elephants sustain healthy populations remain debated [e.g., 91]. Although they are flexible, eating diverse foods in numerous habitats, they require drinking water [Fig. 2a, 92, 93-95]. They do not always use the most accessible water [96], but prefer (or excavate) clean sources [97-99]. Our own observations in mountain forest landscapes indicate that elephants have less impact on forest areas farther away from favoured water sources [100].

Proboscideans are vulnerable to various health disorders. Both African elephant species are susceptible to various parasites which influence their fitness and survival [101-104]. Their viruses are little studied but do cause sporadic disease outbreaks and mortality [105, 106]. More is known about bacterial infections, such as tuberculosis $M y$ cobacterium tuberculosis (Zopf), that have long been recognised to afflict these animals [107, 108]. The bones from many North American Mastodons (Mammut americanum Blumenbach) indicate tuberculosis - suggesting this disease contributed to their extinction [109]. The bones of the Eurasian Woolly mammoth also indicate frequent poor health, even among juveniles, though in this case dietary deficiencies have been suggested [110].

Water and disease are not the only influences. There is evidence that Bush elephant populations are constrained by food and fecundity [111-113]. Droughts not only restrict access to clean water but can also lead to starvation as animals aggregate around water and deplete available vegetation [114].
Predators also impact elephants [111, 113]. Bush elephants up to seven years old remain vulnerable to predation by lions (Panthera leo Linnaeus) $[112,113]$. Younger juveniles are vulnerable to hyaena (Crocuta Erxleben) too and are especially vulnerable when animals must aggregate around limited water, as occurs during droughts $[112,113]$.

The giants of the past suffered predation too. Van Valkenburgh and colleagues [115] show that even the Pleistocene's largest herbivores remained vulnerable to predation and drought. In brief, they show that juvenile mammoths and mastodons were vulnerable to felids and pack hunting canids (several of these carnivores being substantially larger than their present-day relatives).

Gorshkov and Makarieva [1] suggest that a "population of large animals can increase to a point when the animals will consume all young seedlings produced by mature trees". While we lack clear evidence either way, it is doubtful that populations would grow, or even persist, once food was depleted - especially if it coincided with extended droughts, stress-related diseases, restricted water availability, and increased predation. There may be some lag in the density dependent dynamics, but such populations will decline. The question remains whether, and under what circumstances, such populations can nonetheless destroy enough forest to impact the climate and how such processes may advance.

\section{Savannas in an evolutionary context}

Gorshkov and Makarieva [1] note that the process of degradation that they predict from overstocking with herbivores "is described and studied for savannas". In the next sections I review the interplay between savannas and tree cover, including forest, and the influence of herbivores. First, what is a "forest" and what is a "savanna"? Forests and savannas have both been defined in many ways that can make it hard to compare quantitative studies. Here, taking a broad approach, I consider forests as dense (closed or near closed) tree cover and savanna as tropical grasslands with scattered woody vegetation.

The expansion of savannas between 3 and 8 million years ago is poorly understood [116]. Most savanna grasses are $\mathrm{C} 4$ species adapted to open conditions and periodic drought [117-119]. Stable isotopes permit us to trace this vegetation through time [see 120,121, 122]. This reveals that the global expansion was neither smooth nor simultaneous [123-125]. While hoofed ungulates are sometimes highlighted as central in the emergence of C4 savannas [e.g., 126], these biomes also ex- 
panded into locations without such ungulates: for example, Australia with its marsupials [127] and Madagascar [128] where pygmy hippos and giant tortoises grazed [129, 130].

Savannas are one, comparatively recent, result of the long coevolution among plants, fires, and herbivores. Exploring these relationships into deep time offers evolutionary context. I start with fire.

The likelihood of wildfires is influenced by the levels of atmospheric oxygen and this has varied markedly over time [131]. Experiments show that if oxygen levels are below $13 \%$, wildfires will neither ignite nor spread irrespective of fuel moisture content. With oxygen levels between 13 and $16 \%$ oxygen, only dry plant material can sustain a fire. Above $25 \%$ oxygen fires would become widespread, even in wetter climates while at levels $>35 \%$ fires might not be extinguished [132]. As a result of these relationships, and their impact on carbon burial (see below), it is believed that fire played a role in determining levels of both atmospheric carbon dioxide and oxygen [132].

Evidence of fires occurs throughout the fossil record and often in abundance (charcoal and charrelated material). Fire was present from the beginning: the first terrestrial plants (Silurian) and forests (Devonian) burned [132-134]. Multi-storied Devonian forests formed in wet habitats and were generally dominated by deep-rooted spore producing Archaeopterids (Progymnospermopsida). These are sometimes considered the first trees, with woody trunks and a height of over $30 \mathrm{~m}$ [135]. These forests sheltered a range of other organisms including climbing plants and arthropods, while their riverine channels sheltered not only a diverse range of freshwater fishes but also water dependent tetrapod vertebrates. Detailed studies in fossil materials from such forests reveals fragments of charcoal, some of which preserve anatomical structures suggesting they result from Rhacophyton, a shallow-rooted zygopterid fern [136]. As an aside, I note that the expansion of this terrestrial vegetation, with its impacts on weathering and increased nutrients entering the marine environments, may have contributed to the atmospheric changes that led to the late Devonian extinctions [134, 137].

Atmospheric oxygen peaked at around $35 \%$ in the Permo-Carboniferous ( $\sim 300$ million years ago or "mya") [138] facilitating gigantism in insects and coaxing vertebrates onto land. This was nonetheless a time of low atmospheric carbon, and extensive glaciation. Fires were widespread among the forests that thrived in wet environments [139, 140]. Trees reached $50 \mathrm{~m}$ tall and intermittent fires burned as high as the forest canopy [140, 141]. The common ancestor of modern conifers at this time appears to have been serotinous (i.e. not re- leasing seeds without sufficient heat) - an adaptation to fire in modern ecosystems [142, 143]. Fossils suggest that plants in these forests developed other adaptations to fire such as the thick corky stem surfaces on the tree-like Calamites and lycopsids that charred rather than burned [138, 139]. The charred material that resulted from these burned forests contributed to coal formation. For example, most major coal deposits originate in the forests of the Westphalian 313-304 mya. Fusain, a compound resulting from the incomplete combustion of plant matter, comprises much of the carbon in these coals which is interpreted as a consequence of the repeated incomplete burning of these fire adapted forests [138]. (Limited ability to metabolise woody material may also have played a role. For example, molecular analyses suggest that the common ancestor of termites and the wooddigesting roach genus Cryptocercus separated more recently at about 170 mya [144]).

After the Permo-Carboniferous oxygen and fire peak, a subsequent decline in atmospheric oxygen reduced wildfires to much lower levels for over one-hundred million years [145]. The widespread loss of forests 305 mya heralded the end of coal formation, and the start of a drier era with more fragmented vegetation which greatly influenced the diversification of surviving tetrapods (early amphibians and reptiles) [146]. Fires and fire ecologies flourished again 140 mya when oxygen levels reached $28 \%$ making the mid-Cretaceous "one of the most flammable periods in the Earth's history" [145]. Many adaptations seen in modern plants, such as fire dependent seed release and germination, evolved at that time [145, 147]. Furthermore, many modern vegetation types are both flammable and adapted to fire $[148,149]$. So, how does this compare with herbivory?

Like fire, herbivory by large vertebrates can also be assessed from fossil evidence. Terrestrial megaherbivores have likely included browsers since Gondwana's Permian glossopterid forests supported large dinocephalian and anomodont therapsids over 250 million years ago [150] but the evolutionary and ecological implications remain hard to discern in the fossil record. Studies of skull shape, dentition and tooth wear can help distinguish grazers from browsers among therapsids, dinosaurs and other taxa [151,152]. Occasionally stomach contents or coprolites preserve sufficient structure to further indicate that these ancient giants ingested woody material, but interpretation remains contentious and provides little insight into the prevalence and significance of browsing [153155]. In one unusually well-preserved example, twig fragments "likely from conifers belonging to the Cupressaceae or Taxodiaceae" were found in 
Montana USA, in fossilised droppings attributed to the two-tonne hadrosaurs (Maiasaura peeblesorum Horner \& Makela) from 74-80 mya. Even in this example, the authors remained uncertain if the woody material derived from live or dead trees [154].

How did plants respond to herbivory? In the current era we see plants producing phytoliths, resins, stings, irritant hairs, trichomes, sticky latex, spines, thorns, prickles, glochids, other spinose structures, or by thigmonasty/seismonasty (response to touch), association with ants, mimicry, camouflage or the manufacture, and/or accumulation, of chemical defences that inhibit digestion, reduce palatability, and/or are toxic (phenolics, alkaloids, terpenoids, metal ions, etc.). There are also defences that involve mechanical strength, toughness and resistance to damage, and strategies that involve plant architectures that obstruct access. Few such defences can be inferred confidently from fossils. An exception is the woody spines which have been observed since the Triassic [156].

What preceded modern savannas? We know little about the ecology of the open Paleogene environments and their faunas [for a review, see 157]. A phylogenetic investigation into spiny vegetation in Africa suggests browsers maintained open vegetation millions of years before modern grassy savannas existed [158]. What about the understorey? Coe and colleagues [159] speculated that "fern prairies" supported grazing dinosaurs in the Mesozoic. This seems consistent with modern-day ferns that maintain persistent clearings in both tropical and temperate forests [160-162]. For example, like many forests worldwide, Bwindi, Uganda, has extensive clearings supporting bracken fern Pteridium aquilinum (L.) Kuhn [some persisting > 40 years, 163]. Few animals eat this fern at Bwindi, though Bush elephants (and occasionally also bush pigs Potamochoerus larvatus F. Cuvier) appear exceptions: according to local people the elephants hold the fronds with their trunks and then, by swinging their front leg from side to side, slice the rhizomes from the ground using their toenails. This leaves extensive areas of open soil that are soon recolonised by bracken [100]. Our data show that few tree seeds manage to reach, germinate and establish in these fern-dominated areas $[164,165]$, and those seedlings that establish, even if not sought out as food, have an estimated $61 \%$ chance of severe damage each year due largely to the activities of animals [100]. While elephants help maintain these clearings, they are not essential, and extensive and persistent bracken patches also occur without elephants, for example, in Nyungwe Forest (Rwanda), which has suffered recurrent fires [166].
The initial spread of Africa's C4 grasses, assumed to be the birth of the savannas, coincides with the instabilities of the "Messinian Event" 6.05.3 mya - when the Mediterranean dried up repeatedly and the world's oceans became less saline paving the way for the subsequent glacials [167, 168]. Savanna expansions had various consequences [see, e.g., 169]. The influence of smoke (and related emissions) from frequent grassfires on rain and lightning (potential ignitions) remains uncertain, but less forest and more grass will generally increase the likelihood of fires that favour savanna thus entailing a positive feedback [126, 170]. Any regional decline in tree cover reduces rainfall, increasing the likelihood of fire and further forest loss. If we couple this idea with more recent insights into the powerful feedbacks maintaining wet climates within continents there is no doubt that forest loss will disrupt the climate and ultimately risks tipping whole regions from wet to arid [2, 171-173].

There are global feedbacks too. For example, savanna expansion (perhaps counterintuitively, as I explain below) reduces atmospheric carbon dioxide and increases atmospheric oxygen and thus boosts the worldwide likelihood of fires [126, 138, 174]. Such expansions, when combined with other changes such as reduced ocean salinity and orbital shifts [175], led into the unstable Pleistocene with extended arid glaciations, sea level changes, fluctuating atmospheric carbon dioxide and shifting vegetation [176-179].

How do vegetation fires influence atmospheric composition? Over geological time scales atmospheric oxygen levels are modified by the global carbon and sulphur cycles - for a fuller account see Berner and colleagues [138]. Briefly here focusing on the carbon aspect, vegetation fires enhance sequestration of carbon from the atmosphere through the creation and accumulation of charred pyrogenic material in the soil as this is more resilient to breakdown than other plant-derived organic matter [174]. So, while any individual fire will reduce oxygen and increase carbon-dioxide, frequent fires can lead to carbon being removed from the atmosphere and buried - as seen in the formation of the carboniferous coals mentioned above. While this mechanism has been neglected in models of the global carbon cycle there have been recent calls for this to change [180]. While various other processes such as weathering play a role too, there is good evidence of a positive feedback where higher oxygen leads to more fires and more charcoal production and burial further increases oxygen $[138,181]$.

Generally, forest retreat is considered a consequence of the glaciations. Yet, feedbacks between atmospheric moisture and circulation suggest that 
changes in forest cover could be influential in determining latitudinal temperature gradients too [182-184]. In this context, any regional change in the dynamics between tree cover and other vegetation would be important and could help explain why vegetation change often varied among sites and periods [178, 185, 186]. Unfortunately, we lack the data needed to characterise these relationships across the tropics. Furthermore, we see elsewhere that even when good data are available, detailed interpretation remains challenging [e.g., 187, 188, 189].

\section{Savanna-forest dynamics}

Savanna-forest dynamics have been extensively studied. Yet, as Hoffmann and colleagues [190] note "there is no consensus regarding the relative importance of climate, fire, hydrology, herbivory and soil characteristics in mediating the balance between these biomes". Observations from tropical Africa show that closed forests can occur with as little as $700 \mathrm{~mm}$ of annual rain - but nonetheless tree cover often remains scattered and open even in much wetter sites [Fig. 3a, 191]. As I shall examine in this section, such open vegetation is often attributed to fire (the role of animals is examined in the subsequent section). While savanna and forest are sometimes considered alternative stable states [192], this label is somewhat misleading as savanna tree cover, rather than being stable, appears in constant flux [193]. Local investigations show that site conditions are influential (e.g., soil moisture, termite activity and access to grazers, Fig. 3b). Nonetheless, fire appears key. Fire is not choosy about nutritional attributes and has a vastly larger appetite than any herbivore. According to one simplified simulation, without fire global tree cover would double [see 194].
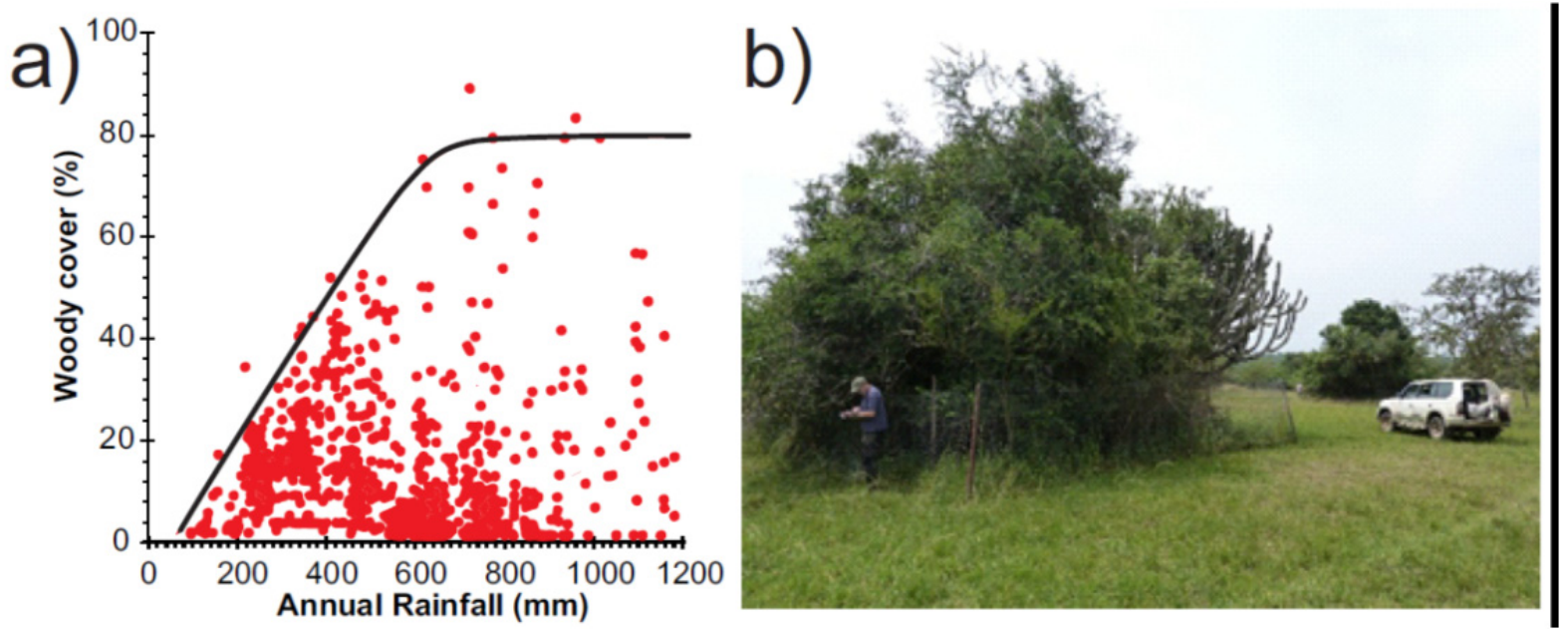

Fig. 3. $a$ - woody cover versus annual rainfall, based on 854 sites across Africa and redrawn from Sankaran, Hanan [191] showing a 99th quantile piecewise linear regression. Trees are absent below $100 \mathrm{~mm}$ rainfall, and the maximum cover rises markedly between 100 and $650 \mathrm{~mm}$, but most sites achieve a woody cover that is well below the maximum; $b$ - our work in Lake Mburu National Park, Uganda, (mean annual temperature and rainfall: $20.7^{\circ} \mathrm{C}$ and $865 \mathrm{~mm}$ ) suggests that tree cover in this landscape is increasing, a process that is facilitated by the presence of termite mounds as well as by fencing - as in this image that excludes large herbivores [but not fire, see, e.g., 265]. Photograph by D. Sheil

Savanna grasses possess characteristics - e.g., rhizomes and protected meristems - that tolerate recurrent grazing and fires [126, 195]. Grasses evolved to be flammable. The rapid growth and slow decomposition of savanna grasses fuel fires that can suppress the regeneration of trees.

While many details about the evolution of flammability as an adaptive trait remain debated [148, 196-198] there are various modern day species, and indeed biomes, that are not only flammable but depend directly or indirectly on fire [199]. The question of how flammability is selected is made more complex by indications that there may be more than two - flammable versus non flammable - strategies [149]. In any case, some model-based results suggest flammability can be selected for when feedbacks favour the expansion of flammable species from more fire-prone into less fire-prone areas [200]. In addition, recent theory suggests flammability can be selected for under certain conditions including the delayed succession that can result from more frequent fires [201].

Mature savanna trees typically possess thick fire-resistant bark [202, 203] - but saplings remain thin barked and vulnerable, and they take time to 
grow large enough to survive fire. Frequent fires mean the above-ground parts of small and stillvulnerable stems are killed [190, 204]. Successful tree recruitment requires sufficient time between fires for saplings to reach less vulnerable dimensions [205]. Tree cover, in contrast to grass, typically reduces fires (e.g., through increased shade and moisture, and reduced wind) and thus favours the recruitment of more trees. Once tree cover becomes dense enough fires become less likely. Observations in Southern Africa show that fire frequency declines markedly once tree cover exceeds $40 \%$ [206]. If tree cover is maintained, and the necessary seeds and diaspores are present, a dense woodland composed of savanna trees can develop into a closed canopy forest. Such successional developments can take decades or centuries [72, 207, 208].

Typical forest trees are specialised to establish and compete in shady forests: most are thin-barked and sensitive to fire even when mature $[202,203$, 209]. Once they are established, most broad-leaved tropical forests are damp places that do not readily burn. Nonetheless, a usually non-flammable forest can become flammable following extended droughts - such events can kill larger trees and favour the accumulation of dry litter that can fuel fires and kill small trees [something I have seen in Borneo, see 209]. Such fires tend to kill many stems, opening the canopy, thus generating the fuel and lower humidity that increases vulnerability to, and thus the likelihood of, future fires [210].

The frequency and significance of fire in wet tropical forest prior to human presence is uncertain. We do know that such fires are almost always associated with droughts that allow dead biomass to become flammable. There have certainly been droughts and fires in otherwise wet forests before extensive human impacts. An explorer who visited Borneo in 1879 (before extensive forest loss) reported a drought that lasted over eight months, leaving a third of forest trees dead [Bock 1881 quoted in 211]. There is also evidence of fires going back at least ten thousand years [212]. However, modern humans have been active in Borneo for at least fifty thousand years [213] and their impacts may be greater than has been generally assumed [214]. If we want to look at continental forests prior to any human impacts, we turn to Amazonia: unfortunately, the evidence here is inconclusive. Charcoal in Amazonian soils have been dated back to over nine thousand years ago but can still be interpreted as having human origins [e.g., 215]. Some site-based studies show no sign of fire over many centuries despite human presence [e.g., 216]. Lake sediment cores reveal at least some charcoal particles arriving up to fifty thousand years ago (before humans arrived) but the sources remain uncertain [217]. What is widely accepted is that human activities greatly increased the likelihood of forest fires [210]. There is also increasing awareness that such fires can, through multiple mechanisms (relating to reduced humidity, less reliable rain and increased and more frequent availability of flammable fuel) enhance the likelihood of subsequent droughts and fires [2, 172, 218-220].

In the long term, systems can switch between states, forest or non-forest, depending on details of the fire regime [190, 205]. Outcomes depend on conditions during the brief period of fire ignition, combustion and contagion (spread). Ignition appears the least understood.

Prior to human activities, ignition had to arise naturally. There have been various suggestions how this can occur: lightning strikes, spontaneous ignition within composting biomass, concentrated sunlight, sparks (e.g. generated by rock-falls, or animals), friction (e.g. tree stems grinding against each other in wind), volcanic activity, meteorites, and various chemical processes (such as combustion of phosphines [221]). The plausibility and significance of these are uncertain, but lightning is generally judged the dominant (but not sole) cause of ignition in natural systems [222-224]. There are also situations, such as when coal (or peat) seams include openings to air and can ignite spontaneously (or from external fires) [225] and can smoulder in protected conditions for many years and reestablish vegetation fires when conditions permit [212]. Such sustained underground fires have become important in the modern world where roads, mines and related developments have exposed coal. For example, in Indonesia in 1998 it was estimated that 250,000 distinct fires remained burning in subterranean coal seams [225] and were difficult to extinguish [226, 227]. Whether or not ignition events limit the frequency of fires in any location depends also on the scale of the subsequent fires, which is determined by their ability to spread. While the determinants of savanna in a pre-human world remain uncertain, there is little doubt that, along with fire, animals played a significant role.

\section{Animal influences}

Vertebrates can influence the balance between trees and grass in many ways [see, e.g., 228, 229231]. For example, as Gorshkov and Makarieva [1] also note, rodents may remove tree seeds and impede forest establishment. Seed rain far from trees is often low and seed removal rates high [232]. Pigs sometimes achieve high densities and threaten forest regeneration and recovery - though these effects are often transient [233-235]. Sustained 
browsing by abundant antelopes can hinder tree establishment in savannas [236]. Animals can influence the quantities, structure and condition of potential fuel for fires - and thus influence the nature, likelihood, frequency and spatial scale of fires [231]. Animals may even use and spread fire: observations in Northern Australia show that kites and other raptors sometimes seek smouldering sticks (from bush fires or human hearths) and carry them to purposefully start fires elsewhere as a means to flush out prey [237]. Similar claims are known from Africa, Asia and the Americas [M. Bonta quoted in 238].

What about more typical animal behaviours? Browsing generally reduces woody growth and the likelihood that small trees escape fire [239-241]. Grazing generally reduces competition from grass, as well as fire intensity and frequency [231, 242], and thus favours tree establishment [229, 230]. Fluctuations in vertebrate grazers, e.g., following disease or drought, can have a marked impact on tree recruitment [243, 244]. One argument against a particular importance for megaherbivores is the similarity in apparent tree density patterns in Africa (with megaherbivores) and Australia (without) $[245,246]$ though anthropogenic influences may also explain this convergence. As Johnson and colleagues note [228] "our knowledge of the effects of vertebrates on fire is still sparse, as well as being unevenly distributed in geographical and environmental space". Archibald and colleagues [247] are more pessimistic noting that "most savannas globally have lost much of their mammalian fauna". In support of this view, modern day trees possess defences - such as spine-like protuberances high on large stems of various species including Ceiba pentandra (L.) Gaertn. and Zanthoxylum gilletii (De Wild.) P. G. Waterman (Fig. 2d,e) - that appear superfluous without megaherbivores.

The ability of fire to spread depends on the continuity of fuel, and the ability of the fire to cross gaps (e.g. by throwing embers). This is also important where biomes meet. For example, the activity of animals on forest-savanna boundaries can influence permeability to fire and whether the savanna or forest advance at the expense of the other. I have seen the processes operating in both directions in Uganda. For example, in Budongo Forest, low dense evergreen vegetation (Acanthus spp. etc) generally borders the forest and appears to be a barrier to fire. This forest has expanded over recent centuries [72, 207, 248]. Rabongo Forest, in contrast, is contracting as tree cover is lost at its edges. Large relic forest trees occur in the surrounding savanna, outside the current forest, while charring can be seen on tree boles within the forest [DS pers. obs., 95]. Bush elephants and buffalos are especially active at Rabongo: the forest canopy is more open than in Budongo (likely due to limited regeneration), allowing a less humid understorey with a patchy vegetation at the forest edge and litter that sometimes dries out and permits fire to enter. In Gabon, Forest elephants are said to trample forest edges creating firebreaks [76], though whether this boundary is static or "natural" is uncertain (one common fruiting species attracting these animals is guava, Psidium guineense Sw., a naturalised alien species that favours forest edges [76]).

\section{Conservation comments}

A clarification is needed. Sometimes conservationists highlight what they consider the implied "positive role" of certain organisms to argue for their conservation. This may give the impression that giving credence and emphasis to "destructive roles", for example, to megafauna reducing forest cover, is unsupportive. For that reason, I underline that I support both objective science (free of normative labels) and conservation (led by shared norms). I should also underline that forests are not the only biome requiring conservation: many savannas along with many other non-forest formations maintain important biodiversity and require protection. Regardless of how we view any ecological impacts of megafauna, the need for their conservation remains real and urgent. Furthermore, it remains true that elephants and other megaherbivores generate, maintain and modify the environments, habitat features and processes on which many other species depend.

As we have already seen, by maintaining open habitats elephants and other megaherbivores benefit the organisms that require these conditions, but they have significant additional influences too. They excavate and maintain pools that provide water in areas and seasons when water is otherwise unavailable [99]. They can influence the availability of key nutrients [249]. They may dig for access to salt, or modify land-surfaces and waterways [250]. They can impact the vegetation so as to facilitate other herbivores too $[40,251]$. There are also plants considered dependent on elephants or other large animals for effective seed dispersal [252-255]. Such relationships are not limited to elephants or even the tropics [256, 257]. The relevance of these additional relationships for tree cover, and related feedbacks, remains largely unknown. Whatever the past implications, the risks we now face are almost exclusively of our own making: the world's remaining megaherbivores must be valued and protected. 


\section{Synthesis}

I agree with Gorshkov and Makarieva [1] that forests play a key role in stabilising the conditions of our planet. It is important to understand any threats to this stability, especially the conditions where positive feedbacks dominate. These are the "tipping points" where a small change has dramatic consequences [258, 259]. Some feedbacks operate at regional to continental scales [260] - for example, forest loss causing desiccation in Australia $[261,262]$, or tipping the Amazon from wet to dry [263]. Other feedbacks are potentially global, such as when rising atmospheric carbon dioxide promotes the release of additional carbon into the atmosphere [264]. While we know such feedbacks exist and are potentially powerful, our proximity to such tipping points in the past is less clear. The extent to which megaherbivores might reduce forests, or modify their hydrological influences, is also unclear. Observations of Bush elephants suggest that they can reduce tree cover and help maintain more open habitats that may also yield more elephant food and thus permit population growth. Furthermore, there are situations, as seen with persistent clearings, where forest is slow to recover, and impacts will accumulate while losses outpace recovery.
It is plausible that there have been periods when forest loss contributed to, or even determined, climatic instability and that megaherbivores influenced these dynamics. The Pleistocene glaciations coincide with extended periods of forest retreat, and of expanded aridity in Africa and elsewhere, and megaherbivores may have been influential. The wider role of megaherbivores in a world prior to humans remains difficult to infer when viewed from within a world bearing nearly eight billion people. There are plenty of uncertainties and unanswered questions, along with scope for speculation. Nonetheless, the overall story seems more complex than Gorshkov and Makarieva [1] imply. Rather than highlighting megaherbivores alone, I would point to fire and flammable biomes as warranting additional scrutiny (savanna, grasslands and various seasonal forests). When fire is involved, body-size becomes less fundamental - consider the potential impact of one ape with matches or a firecarrying kite [237]. Furthermore, whatever conclusions may be reached, nothing in these discussions argues against the real and urgent need for conservation of the world's remaining megaherbivores.

\section{Библиографический список}

1. Gorshkov, V. G. Key ecological parameters of immotile versus locomotive life / V. G. Gorshkov, A. M. Makarieva // Russian Journal of Ecosystem Ecology. - 2020. - Vol. 5 (1). - DOI 10.21685/2500-0578-2020-1-1.

2. Sheil, D. Forests, atmospheric water and an uncertain future: the new biology of the global water cycle / D. Sheil // Forest Ecosystems. - 2018. - Vol. 5 (19). - P. 1-22. - DOI 10.1186/s40663-018-0138-y.

3. Paul, G. Determining the largest known land animal: a critical comparison of differing methods for restoring the volume and mass of extinct animals / G. Paul // Annals of Carnegie Museum. - 2019. - Vol. 85 (4). - P. 335-358. DOI 10.2992/007.085.0403.

4. Burness, G. P. Dinosaurs, dragons, and dwarfs: The evolution of maximal body size / G. P. Burness, J. Diamond, T. Flannery // Proceedings of the National Academy of Sciences of the United States of America. - 2001. - Vol. 98 (25). - P. 14518-14523. - DOI 10.1073/pnas.251548698.

5. Whitlock, J. A. Re-evaluation of Australodocus bohetii, a putative diplodocoid sauropod from the Tendaguru Formation of Tanzania, with comment on Late Jurassic sauropod faunal diversity and palaeoecology / J. A. Whitlock // Palaeogeography, Palaeoclimatology, Palaeoecology. - 2011. - Vol. 309 (3-4). - P. 333-341. DOI 10.1016/j.palaeo.2011.07.001.

6. Barrett, P. M. Paleobiology of herbivorous dinosaurs / P. M. Barrett // Annual Review of Earth and Planetary Sciences. - 2014. - Vol. 42. - P. 207-230. - DOI 10.1146/annurev-earth-042711-105515.

7. Larramendi, A. Shoulder height, body mass, and shape of proboscideans / A. Larramendi // Acta Palaeontologica Polonica. - 2016. - Vol. 61 (3). - P. 537-575. - DOI 10.4202/app.00136.2014.

8. Fortelius, M. The largest land mammal ever imagined / M. Fortelius, J. Kappelman // Zoological Journal of the Linnean Society. - 2008. - Vol. 108 (1). - P. 85-101. - DOI 10.1111/j.1096-3642.1993.tb02560.x.

9. Collapse of the world's largest herbivores / W. J. Ripple, T. M. Newsome, C. Wolf, R. Dirzo, K. T. Everatt, M. Galetti, M. W. Hayward, G. I. H. Kerley, T. Levi, P. A. Lindsey, D. W. Macdonald, Y. Malhi, L. E. Painter, C. J. Sandom, J. Terborgh, B. Van Valkenburgh // Science Advances. - 2015. - Vol. 1 (4). P. e1400103. - DOI 10.1126/sciadv.1400103.

10. Hansen, D. M. The forgotten megafauna / D. M. Hansen, M. Galetti // Science. - 2009. - Vol. 324 (5923). P. 42-43. - DOI 10.1126/science.1172393.

11. Ecological and evolutionary legacy of megafauna extinctions / M. Galetti, M. Moleón, P. Jordano, M. M. Pires, P. R. Guimarães Jr., T. Pape, E. Nichols, D. Hansen, J. M. Olesen, M. Munk, J. S. de Mattos, A. H. Schweiger, N. Owen-Smith, C. N. Johnson, R. J. Marquis, J.-C. Swenning // Biological Reviews. - 2018. - Vol. 93 (2). P. 845-862. - DOI 10.1111/brv.12374. 
12. Gill, J. L. Ecological impacts of the late Quaternary megaherbivore extinctions / J. L. Gill // New Phytologist. 2014. - Vol. 201 (4). - P. 1163-1169. - DOI 10.1111/nph.12576.

13. Isotopic reconstruction of Proboscidean habitats and diets on Java since the Early Pleistocene: Implications for adaptation and extinction / M. R. Puspaningrum, G. D. van den Bergh, A. R. Chivas, E. Setiabudi, I. Kurniawan // Quaternary Science Reviews. - 2020. - Vol. 228. - P. 106007. - DOI 10.1016/j.quascirev.2019.106007.

14. Diet and habitat for six American Pleistocene proboscidean species using carbon and oxygen stable isotopes / V. A. Pérez-Crespo, J. L. Prado, M. T. Alberdi, J. Arroyo-Cabrales, E. Johnson // Ameghiniana. - 2016. Vol. 53 (1). - P. 39-51. - DOI 10.5710/AMGH.02.06.2015.2842.

15. Saarinen, J. Tooth wear and diets of extant and fossil xenarthrans (Mammalia, Xenarthra)-applying a new mesowear approach / J. Saarinen, A. Karme // Palaeogeography, Palaeoclimatology, Palaeoecology. - 2017. Vol. 476. - P. 42-54. - DOI 10.1016/j.palaeo.2017.03.027.

16. Lister, A. Evolution and dispersal of mammoths across the Northern Hemisphere / A. Lister, A. Sher // Science. 2015. - Vol. 350 (6262). - P. 805-809. - DOI 10.1126/science.aac5660.

17. Asevedo, L. Ancient diet of the Pleistocene gomphothere Notiomastodon platensis (Mammalia, Proboscidea, Gomphotheriidae) from lowland mid-latitudes of South America: Stereomicrowear and tooth calculus analyses combined / L. Asevedo, G. R. Winck, D. Mothé, L. S. Avilla // Quaternary International. - 2012. - Vol. 255. P. 42-52. - DOI 10.1016/j.quaint.2011.08.037.

18. Stuart, A. The extinction of woolly mammoth (Mammuthus primigenius) and straight-tusked elephant (Palaeoloxodon antiquus) in Europe / A. Stuart // Quaternary International. - 2005. - Vol. 126-128. - P. 171-177. DOI 10.1016/j.quaint.2004.04.021.

19. A comprehensive genomic history of extinct and living elephants / E. Palkopoulou, M. Lipson, S. Mallick, S. Nielsen, N. Rohland, S. Baleka, E. Karpinski, A. M. Ivancevic, T.-H. To, R. D. Kortschak, J. M. Raison, Z. Qu, T.-J. Chin, K. W. Alt, S. Claesson, L. Dalén, R. D. E. MacPhee, H. Meller, A. L. Roca, O. A. Ryder, D. Heiman, S. Young, M. Breen, C. Williams, B. L. Aken, M. Ruffier, E. Karlsson, J. Johnson, F. Di Palma, J. Alfoldi, D. L. Adelson, T. Mailund, K. Munch, K. Lindblad-Toh, M. Hofreiter, H. Poinar, D. Reich // Proceedings of the National Academy of Sciences of the United States of America. - 2018. - Vol. 115 (11). - P. E2566-E2574. DOI 10.1073/pnas.1720554115.

20. Coupling tooth microwear and stable isotope analyses for palaeodiet reconstruction: the case study of Late Middle Pleistocene Elephas (Palaeoloxodon) antiquus teeth from Central Italy (Rome area) / M. R. Palombo, M. L. Filippi, P. Iacumin, A. Longinelli, M. Barbieri, A. Maras // Quaternary International. - 2005. - Vol. 126-128. P. 153-170. - DOI 10.1016/j.quaint.2004.04.020.

21. Orlova, L. A. New data on the time and place of extinction of the woolly rhinoceros Coelodonta antiquitatis Blumenbach, 1799 / L. A. Orlova, S. K. Vasil'ev, Ya. V. Kuzmin, P. A. Kosintsev // Doklady Biological Sciences. 2008. - Vol. 423 (1). - P. 403-405. - DOI 10.1134/S0012496608060100.

22. Tiunov, A. V. Stable isotope $\left({ }^{13} \mathrm{C} /{ }^{12} \mathrm{C}\right.$ and $\left.{ }^{15} \mathrm{~N} /{ }^{14} \mathrm{~N}\right)$ composition of the woolly rhinoceros Coelodonta antiquitatis horn suggests seasonal changes in the diet / A. V. Tiunov, I. V. Kirillova // Rapid Communications in Mass Spectrometry. - 2010. - Vol. 24 (21). - P. 3146-3150. - DOI 10.1002/rcm.4755.

23. Figueirido, B. Ecomorphological correlates of craniodental variation in bears and paleobiological implications for extinct taxa: an approach based on geometric morphometrics / B. Figueirido, P. Palmqvist, J. A. Pérez-Claros // Journal of Zoology. - 2009. - Vol. 277 (1). - P. 70-80. - DOI 10.1111/j.1469-7998.2008.00511.x.

24. Isotopic evidence for omnivory among European cave bears: Late Pleistocene Ursus spelaeus from the Peştera cu Oase, Romania / M. P. Richards, M. Pacher, M. Stiller, J. Quilés, M. Hofreiter, S. Constantin, J. Zilhão, E. Trinkaus // Proceedings of the National Academy of Sciences of the United States of America. - 2008. - Vol. 105 (2). P. 600-604. - DOI 10.1073/pnas.0711063105.

25. Bargo, M. S. The ground sloth Megatherium americanum: skull shape, bite forces, and diet / M. S. Bargo // Acta Palaeontologica Polonica. - 2001. - Vol. 46 (2). - P. 173-192.

26. Green, J. L. Xenarthran dental microstructure and dental microwear analyses, with new data for Megatherium americanum (Megatheriidae) / J. L. Green, D. Kalthoff // Journal of Mammalogy. - 2015. - Vol. 96 (4). - P. 645657. - DOI 10.1093/jmammal/gyv045.

27. Wroe, S. The size of the largest marsupial and why it matters / S. Wroe, M. Crowther, J. Dortch, J. Chong // Proceedings of the Royal Society B: Biological Sciences. - 2004. - Vol. 271. - P. S34-S36. DOI 10.1098/rsbl.2003.0095.

28. Seasonal migration of marsupial megafauna in Pleistocene Sahul (Australia-New Guinea) / G. J. Price, K. J. Ferguson, G. E. Webb, Y. Feng, P. Higgins, A. D. Nguyen, J. Zhao, R. Joannes-Boyau, J. Louys // Proceedings of the Royal Society B: Biological Sciences. - 2017. - Vol. 284 (1863). - P. 20170785. - DOI 10.1098/rspb.2017.0785.

29. Smith, F. A. Body size downgrading of mammals over the late Quaternary / F. A. Smith, R. E. E. Smith, S. K. Lyons, J. L. Payne // Science. - 2018. - Vol. 360 (6386). - P. 310-313. - DOI 10.1126/science.aao5987.

30. Hempson, G. P. The consequences of replacing wildlife with livestock in Africa / G. P. Hempson, S. Archibald, W. J. Bond // Scientific Reports. - 2017. - Vol. 7 (1). - P. 17196. - DOI 10.1038/s41598-017-17348-4.

31. Grubb, P. Living African elephants belong to two species: Loxodonta africana (Blumenbach, 1797) and Loxodonta cyclotis (Matschie, 1900) / P. Grubb, C. P. Groves, J. P. Dudley, J. Shoshani // Elephant. - 2000. - Vol. 2 (4). P. 1-4. - DOI 10.22237/elephant/1521732169. 
32. Roca, A. L. Genetic evidence for two species of elephant in Africa / A. L. Roca, N. Georgiadis, J. Pecon-Slattery, S. J. O'Brien // Science. - 2001. - Vol. 293 (5534). - P. 1473-1477. - DOI 10.1126/science.1059936.

33. Reconciling apparent conflicts between mitochondrial and nuclear phylogenies in African elephants / Y. Ishida, T. K. Oleksyk, N. J. Georgiadis, V. A. David, K. Zhao, R. M. Stephens, S.-O. Kolokotronis, A. L. Roca // PLOS One. - 2011. - Vol. 6 (6). - P. e20642. - DOI 10.1371/journal.pone.0020642.

34. Roca, A. L. Cyto-nuclear genomic dissociation and the African elephant species question / A. L. Roca, N. Georgiadis, S. J. O'Brien // Quaternary International. - 2007. - Vol. 169. - P. 4-16. - DOI 10.1016/j.quaint.2006.08.008.

35. Genomic DNA sequences from mastodon and woolly mammoth reveal deep speciation of forest and savanna elephants / N. Rohland, D. Reich, S. Mallick, M. Meyer, R. E. Green, N. J. Georgiadis, A. L. Roca, M. Hofreiter // PLOS Biology. - 2010. - Vol. 8 (12). - P. e1000564. - DOI 10.1371/journal.pbio.1000564.

36. Continent-wide survey reveals massive decline in African savannah elephants / M. J. Chase, S. Schlossberg, C. R. Griffin, P. J. Bouché, S. W. Djene, P. W. Elkan, S. Ferreira, F. Grossman, E. M. Kohi, K. Landen // PeerJ. 2016. - Vol. 4. - P. e2354. - DOI 10.7717/peerj.2354.

37. Devastating decline of forest elephants in Central Africa / F. Maisels, S. Strindberg, S. Blake, G. Wittemyer, J. Hart, E. A. Williamson, R. A. Aba'a, G. Abitsi, R. D. Ambahe, F. Amsini et al. // PLOS One. - 2013. Vol. 8 (3). - P. e59469. - DOI 10.1371/journal.pone.0059469.

38. Groves, C. P. Do Loxodonta cyclotis and L. africana interbreed? / C. P. Groves, P. Grubb // Elephant. - 2000. Vol. 2 (4). - P. 4. - DOI 10.22237/elephant/1521732173.

39. Belovsky, G. E. Optimal foraging and community structure: The allometry of herbivore food selection and competition / G. E. Belovsky // Evolutionary Ecology. - 1997. - Vol. 11 (6). - P. 641-672. - DOI 10.1023/ A:1018430201230.

40. Ritchie, M. E. Spatial scaling laws yield a synthetic theory of biodiversity / M. E. Ritchie, H. Olff // Nature. 1999. - Vol. 400 (6744). - P. 557-560. - DOI 10.1038/23010.

41. Laws, R. M. Elephants as agents of habitat and landscape change in East-Africa / R. M. Laws // Oikos. - 1970. Vol. 21 (1). - P. 1-15. - DOI 10.2307/3543832.

42. Laws, R. M. Elephants and their habitats: The ecology of elephants in North Bunyoro, Uganda / R. M. Laws, I. S. C. Parker, R. C. B. Johnstone. - Oxford, England : Clarendon Press, 1975.

43. Kortlandt, A. Vegetation research and the 'bulldozer' herbivores of tropical Africa / A. Kortlandt // Tropical rainforest: the Leeds symposium / ed. by A. C. Chadwick, S. L. Sutton. - Leeds : Leeds Philosophical and Literary Society, 1984. - P. 205-226.

44. Owen-Smith, N. Selective feeding by a megaherbivore, the African elephant (Loxodonta africana) / N. OwenSmith, J. Chafota // Journal of Mammalogy. - 2012. - Vol. 93 (3). - P. 698-705. - DOI 10.1644/11-MAMM-A350.1 .

45. Barnes, R. F. W. Elephant feeding behaviour in Ruaha National Park, Tanzania / R. F. W. Barnes // African Journal of Ecology. - 1982. - Vol. 20 (2). - P. 123-136. - DOI 10.1111/j.1365-2028.1982.tb00282.x.

46. Owen-Smith, N. Megabrowser Impacts on Woody Vegetation in Savannas / N. Owen-Smith, B. Page, G. Teren, D. J. Druce // Savanna Woody Plants and Large Herbivores / ed. by P. F. Scogings, M. Sankaran. - Wiley Online, 2019. - P. 585-611. - DOI 10.1002/9781119081111.ch17.

47. The maximum attainable body size of herbivorous mammals: morphophysiological constraints on foregut, and adaptations of hindgut fermenters / M. Clauss, R. Frey, B. Kiefer, M. Lechner-Doll, W. Loehlein, C. Polster, G. Rössner, W. J. Streich // Oecologia. - 2003. - Vol. 136 (1). - P. 14-27. - DOI 10.1007/s00442-003-1254-z.

48. Clauss, M. The digestive performance of mammalian herbivores: why big may not be that much better / M. Clauss, J. Hummel // Mammal Review. - 2005. - Vol. 35 (2). - P. 174-187. - DOI 10.1111/j.1365-2907.2005. 00062.x.

49. Ullrey, D. E. Elephants: nutrition and dietary husbandry / D. E. Ullrey, S. D. Crissey, H. F. Hintz // East Lansing. MI, USA : Nutrition Advisory Group Handbook, Factsheet 004, 1997. - 19 p.

50. Degradation of Lignin Monomers by the Hindgut Flora of Xylophagous Termites / T. Kuhnigk, E.-M. Borst, A. Ritter, P. Kämpfer, A. Graf, H. Hertel, H. König // Systematic and Applied Microbiology. - 1994. - Vol. 17 (1). P. 76-85. - DOI 10.1016/S0723-2020(11)80034-2.

51. Tsegaye, B. Isolation and Characterization of Novel Lignolytic, Cellulolytic, and Hemicellulolytic Bacteria from Wood-Feeding Termite Cryptotermes brevis / B. Tsegaye, C. Balomajumder, P. Roy // International Microbiology. - 2019. - Vol. 22 (1). - P. 29-39. - DOI 10.1007/s10123-018-0024-z.

52. Asner, G. P. Landscape-scale effects of herbivores on treefall in African savannas / G. P. Asner, S. R. Levick // Ecology Letters. - 2012. - Vol. 15 (11). - P. 1211-1217. - DOI 10.1111/j.1461-0248.2012.01842.x.

53. Asner, G. P. Ecosystem-scale effects of megafauna in African savannas / G. P. Asner, N. Vaughn, I. P. Smit, S. Levick // Ecography. - 2016. - Vol. 39 (2). - P. 240-252. - DOI 10.1111/ecog.01640.

54. Pellegrini, A. F. Woody plant biomass and carbon exchange depend on elephant-fire interactions across a productivity gradient in African savanna / A. F. Pellegrini, R. M. Pringle, N. Govender, L. O. Hedin // Journal of Ecology. - 2017. - Vol. 105 (1). - P. 111-121. - DOI 10.1111/1365-2745.12668.

55. Mosugelo, D. K. Vegetation changes during a 36-year period in northern Chobe National Park, Botswana / D. K. Mosugelo, S. R. Moe, S. Ringrose, C. Nellemann // African Journal of Ecology. - 2002. - Vol. 40 (3). P. 232-240. - DOI 10.1046/j.1365-2028.2002.00361.x. 
56. Tree cover and biomass increase in a southern African savanna despite growing elephant population / J. M. Kalwij, W. F. de Boer, L. Mucina, H. H. T. Prins, C. Skarpe, C. Winterbach // Ecological Applications. - 2010. Vol. 20 (1). - P. 222-233. - DOI 10.1890/09-0541.1.

57. Morrison, T. A. Elephant damage, not fire or rainfall, explains mortality of overstorey trees in Serengeti / T. A. Morrison, R. M. Holdo, T. M. Anderson // Journal of Ecology. - 2016. - Vol. 104 (2). - P. 409-418. DOI 10.1111/1365-2745.12517.

58. Midgley, J. J. Why do elephants damage savanna trees? / J. J. Midgley, D. Balfour, G. I. Kerley // South African Journal of Science. - 2005. - Vol. 101 (5-6). - P. 213-215.

59. Kissa, D. O. Visual detection based distance sampling offers efficient density estimation for distinctive low abundance tropical forest tree species in complex terrain / D. O. Kissa, D. Sheil // Forest Ecology and Management. 2012. - Vol. 263. - P. 114-121. - DOI 10.1016/j.foreco.2011.09.020.

60. Ssali, F. How selective are elephants as agents of forest tree damage in Bwindi Impenetrable National Park, Uganda? / F. Ssali, D. Sheil, J. B. Nkurunungi // African Journal of Ecology. - 2013. - Vol. 51 (1). - P. 55-65. DOI 10.1111/aje.12006.

61. Struhsaker, T. T. Elephants, selective logging and forest regeneration in the Kibale Forest, Uganda / T. T. Struhsaker, J. S. Lwanga, J. M. Kasenene // Journal of Tropical Ecology. - 1996. - Vol. 12 (1). - P. 45-64. DOI $10.1017 / \mathrm{S} 0266467400009305$.

62. Changes in elephant abundance affect forest composition or regeneration? / P. A. Omeja, A. L. Jacob, M. J. Lawes, J. S. Lwanga, J. M. Rothman, C. Tumwesigye, C. A. Chapman // Biotropica. - 2014. - Vol. 46 (6). P. 704-711. - DOI 10.1111/btp.12154.

63. Sheil, D. Forest tree persistence, elephants, and stem scars / D. Sheil, A. Salim // Biotropica. - 2004. - Vol. 36 (4). P. 505-521. - DOI 10.1646/1599.

64. Buechner, H. K. Vegetation Change Induced by Elephants and Fire in Murchison Falls National-Park, Uganda / H. K. Buechner, H. C. Dawkins // Ecology. - 1961. - Vol. 42 (4). - P. 752-766. - DOI 10.2307/1933504.

65. Odoi, J. B. Resilience of forest trees to debarking by elephants in Rabongo Forest, Murchison Falls National Park Uganda : MSc Thesis / J. B. Odoi. - Makerere : Kampala, 2014.

66. Gill, R. A review of damage by mammals in north temperate forests: 3. Impact on trees and forests / R. Gill // Forestry. - 1992. - Vol. 65 (4). - P. 363-388. - DOI 10.1093/forestry/65.4.363-a.

67. Patterns of vole gnawing on saplings in managed clearings in Central European forests / J. Krojerová-Prokešová, M. Homolka, M. Heroldová, M. Barančeková, P. Baňař, J. Kamler, R. Modlinger, L. Purchart, J. Zejda, J. Suchomel // Forest Ecology and Management. - 2018. - Vol. 408. - P. 137-147. - DOI 10.1016/j.foreco.2017.10.047.

68. Drivers and mechanisms of tree mortality in moist tropical forests / N. McDowell, C. D. Allen, K. AndersonTeixeira, P. Brando, R. Brienen, J. Chambers, B. Christoffersen, S. Davies, C. Doughty, A. Duque, F. EspiritoSanto, R. Fisher, C. G. Fontes, D. Galbraith, D. Goodsman, C. Grossiord, H. Hartmann, J. Holm, D. J. Johnson, A. R. Kassim, M. Keller, C. Koven, L. Kueppers, T. Kumagai, Y. Malhi, S. M. McMahon, M. Mencuccini, P. Meir, P. Moorcroft, H. C. Muller-Landau, O. L. Phillips, T. Powell, C. A. Sierra, J. Sperry, J. Warren, C. Xu, X. Xu // New Phytologist. - 2018. - Vol. 219 (3). - P. 851-869. - DOI 10.1111/nph.15027.

69. Hamilton, A. C. A Field Guide to Uganda Forest Trees / A. Hamilton. - Kampala, Uganda : Makerere University, 1981. $-280 \mathrm{p}$.

70. Höft, R. The differential effects of elephants on rain forest communities in the Shimba Hills, Kenya / R. Höft, M. Höft // Biological Conservation. - 1995. - Vol. 73 (1). - P. 67-79. - DOI 10.1016/0006-3207(95)90067-5.

71. Sheil, D. An extreme-value approach to detect clumping and an application to tropical forest gap-mosaic dynamics / D. Sheil, M. Ducey // Journal of Tropical Ecology. - 2002. - Vol. 18 (5). - P. 671-686. - DOI 10.1017/ S0266467402002444

72. Sheil, D. A half century of permanent plot observation in Budongo Forest, Uganda: histories, highlights and hypotheses / D. Sheil // Forest Biodiversity Research, Monitoring and Modeling: Conceptual background and Old World case studies / ed. by F. Dallmeier, J. A. Comiskey. - Paris : M.A.B. UNESCO, 1998. - P. 399-428.

73. Increasing carbon storage in intact African tropical forests / S. L. Lewis, G. Lopez-Gonzalez, B. Sonké, K. AffumBaffoe, T. R. Baker, L. O. Ojo, O. L. Phillips, J. M. Reitsma, L. White, J. A. Comiskey, M. N. Djuikouo, C. E. N. Ewango, T. R. Feldpausch, A. C. Hamilton, M. Gloor, T. Hart, A. Hladik, J. Lloyd, J. C. Lovett, J. R. Makana, Y. Malhi, F. M. Mbago, H. J. Ndangalasi, J. Peacock, K. S. H. Peh, D. Sheil, T. Sunderland, M. D. Swaine, J. Taplin, D. Taylor, S. C. Thomas, R. Votere, H. Wöll // Nature. - 2009. - Vol. 457 (7232). P. 1003-1006. - DOI 10.1038/nature07771.

74. Asynchronous carbon sink saturation in African and Amazonian tropical forests / W. Hubau, S. L. Lewis, O. L. Phillips, K. Affum-Baffoe, H. Beeckman, A. Cuní-Sanchez, A. K. Daniels, C. E. N. Ewango, S. Fauset, J. M. Mukinzi, D. Sheil, B. Sonké, M. J. P. Sullivan, T. C. H. Sunderland, H. Taedoumg, S. C. Thomas, L. J. T. White, K. A. Abernethy, S. Adu-Bredu, C. A. Amani, T. R. Baker, L. F. Banin, F. Baya, S. K. Begne, A. C. Bennett, F. Benedet, R. Bitariho, Y. E. Bocko, P. Boeckx, P. Boundja, R. J. W. Brienen, T. Brncic, E. Chezeaux, G. B. Chuyong, C. J. Clark, M. Collins, J. A. Comiskey, D. A. Coomes, G. C. Dargie, T. Haulleville, M. N. D. Kamdem, J.-L. Doucet, A. Esquivel-Muelbert, T. R. Feldpausch, A. Fofanah, E. G. Foli, M. Gilpin, E. Gloor, C. Gonmadje, S. Gourlet-Fleury, J. S. Hall, A. C. Hamilton, D. J. Harris, T. B. Hart, M. B. N. Hockemba, A. Hladik, S. A. Ifo, K. J. Jeffery, T. Jucker, E. K. Yakusu, E. Kearsley, D. Kenfack, A. Koch, M. E. Leal, A. Levesley, J. A. Lindsell, J. Lisingo, G. Lopez-Gonzalez, J. C. Lovett, J.-R. Makana, Y. Malhi, A. R. Marshall, 
J. Martin, E. H. Martin, F. M. Mbayu, V. P. Medjibe, V. Mihindou, E. T. A. Mitchard, S. Moore, P. K. T. Munishi, N. N. Bengone, L. Ojo, F. E. Ondo, K. S. H. Peh, G. C. Pickavance, A. D. Poulsen, J. R. Poulsen, L. Qie, J. Reitsma, F. Rovero, M. D. Swaine, J. Talbot, J. Taplin, D. M. Taylor, D. W. Thomas, B. Toirambe, J. T. Mukendi, D. Tuagben, P. M. Umunay, G. M. F. van der Heijden et al. // Nature. - 2020. - Vol. 579 (7797). - P. 80-87. DOI 10.1038/s41586-020-2035-0.

75. White, L. J. Group composition and diet of forest elephants, Loxodonta africana cyclotis Matschie 1900, in the Lopé Reserve, Gabon / L. J. White, C. E. Tutin, M. Fernandez // African Journal of Ecology. - 1993. - Vol. 31 (3). P. 181-199. - DOI 10.1111/j.1365-2028.1993.tb00532.x.

76. The role of forest elephants in shaping tropical forest-savanna coexistence / A. W. Cardoso, Y. Malhi, I. Oliveras, D. Lehmann, J. E. Ndong, E. Dimoto, E. Bush, K. Jeffery, N. Labriere, S. L. Lewis, L. T. J. White, W. Bond, K. Abernethy // Ecosystems. - 2020. - Vol. 23. - P. 602-616. - DOI 10.1007/s10021-019-00424-3.

77. Megafaunal influences on tree recruitment in African equatorial forests / J. Terborgh, L. C. Davenport, R. Niangadouma, E. Dimoto, J. C. Mouandza, O. Scholtz, M. R. Jaen // Ecography. - 2016. - Vol. 39 (2). - P. 180-186. DOI 10.1111/ecog.01641.

78. Klaus, G. Geophagy by large mammals at natural licks in the rain forest of the Dzanga National Park, Central African Republic / G. Klaus, C. Klaus-Hügi, B. Schmid // Journal of Tropical Ecology. - 1998. - Vol. 14 (6). P. 829-839. - DOI 10.1017/S0266467498000595.

79. Turkalo, A. K. Long-term monitoring of Dzanga Bai forest elephants: forest clearing use patterns / A. K. Turkalo, P. H. Wrege, G. Wittemyer // PLOS One. - 2013. - Vol. 8 (12). - P. e85154. - DOI 10.1371/ journal.pone.0085154.

80. Carbon stocks in central African forests enhanced by elephant disturbance / F. Berzaghi, M. Longo, P. Ciais, S. Blake, F. Bretagnolle, S. Vieira, M. Scaranello, G. Scarascia-Mugnozza, C. E. Doughty // Nature Geoscience. 2019. - Vol. 12 (9). - P. 725-729. - DOI 10.1038/s41561-019-0395-6.

81. Species matter: Wood density influences tropical forest biomass at multiple scales / O. L. Phillips, M. J. P. Sullivan, T. R. Baker, A. M. Mendoza, P. N. Vargas, R. Vásquez // Surveys in Geophysics. - 2019. - Vol. 40. P. 913-935. - DOI 10.1007/s10712-019-09540-0.

82. Connell, J. H. Tropical rain forests and coral reefs as open nonequilibrium systems / J. H. Connell // Population Dynamics / ed. by R. M. Anderson, B. D. Turner, L. R. Turner. - UK : British Ecological Society, 1979. - P. 141163.

83. Fineblum, W. L. Tradeoff between resistance and tolerance to herbivore damage in a morning glory / W. L. Fineblum, M. D. Rausher // Nature. - 1995. - Vol. 377 (6549). - P. 517-520. - DOI 10.1038/377517a0.

84. Cipollini, D. 8 costs of resistance in plants: From theory to evidence / D. Cipollini, D. Walters, C. Voelckel // Annual Plant Reviews. - 2014. - Vol. 47. - P. 263-307. - DOI 10.1002/9781119312994.apr0512.

85. Darwin, C. On the Origin of Species by Means of Natural Selection / C. Darwin. - London, UK : John Murray, 1859.

86. Podani, J. How fast does Darwin's elephant population grow? / J. Podani, Á. Kun, A. Szilágyi // Journal of the History of Biology. - 2018. - Vol. 51 (2). - P. 259-281. - DOI 10.1007/s10739-017-9488-5.

87. Lee, P. C. The reproductive advantages of a long life: longevity and senescence in wild female African elephants / P. C. Lee, V. Fishlock, C. E. Webber, C. J. Moss // Behavioral Ecology and Sociobiology. - 2016. - Vol. 70 (3). P. 337-345. - DOI 10.1007/s00265-015-2051-5.

88. Foley, C. A. H. Rapid population growth in an elephant Loxodonta africana population recovering from poaching in Tarangire National Park, Tanzania / C. A. H. Foley, L. J. Faust // Oryx. - 2010. - Vol. 44 (2). - P. $205-212$. DOI 10.1017/S0030605309990706.

89. Calef, G. W. Maximum rate of increase in the African elephant / G. W. Calef // African Journal of Ecology. 1988. - Vol. 26 (4). - P. 323-327. - DOI 10.1111/j.1365-2028.1988.tb00984.x.

90. Turkalo, A. K. Demography of a forest elephant population / A. K. Turkalo, P. H. Wrege, G. Wittemyer // PLOS One. - 2018. - Vol. 13 (2). - P. e0192777. - DOI 10.1371/journal.pone.0192777.

91. Gough, K. F. Demography and population dynamics in the elephants Loxodonta africana of Addo Elephant National Park, South Africa: is there evidence of density dependent regulation? / K. F. Gough, G. I. H. Kerley // Oryx. - 2006. - Vol. 40 (4). - P. 434-441. - DOI 10.1017/S0030605306001189.

92. The spatial scaling of habitat selection by African elephants / H. J. de Knegt, F. van Langevelde, A. K. Skidmore, A. Delsink, R. Slotow, S. Henley, G. Bucini, W. F. de Boer, M. B. Coughenour, C. C. Grant, I. M. A. Heitkönig, M. Henley, N. M. Knox, E. M. Kohi, E. Mwakiwa, B. R. Page, M. Peel, Y. Pretorius, S. E. van Wieren, H. H. T. Prins // Journal of Animal Ecology. - 2011. - Vol. 80 (1). - P. 270-281. - DOI 10.1111/j.13652656.2010.01764.x.

93. Western, D. Water availability and its influence on the structure and dynamics of a savannah large mammal community / D. Western // African Journal of Ecology. - 1975. - Vol. 13 (3-4). - P. 265-286. - DOI 10.1111/j.13652028.1975.tb00139.x.

94. Climate influences thermal balance and water use in African and Asian elephants: physiology can predict drivers of elephant distribution / R. C. Dunkin, D. Wilson, N. Way, K. Johnson, T. M. Williams // Journal of Experimental Biology. - 2013. - Vol. 216 (15). - P. 2939-2952. - DOI 10.1242/jeb.080218.

95. Buss, I. O. Some observations on food habits and behavior of the African elephant / I. O. Buss // The Journal of Wildlife Management. - 1961. - Vol. 25 (2). - P. 131-148. - DOI 10.2307/3798671. 
96. Chamaillé-Jammes, S. African elephants adjust speed in response to surface-water constraint on foraging during the dry-season / S. Chamaillé-Jammes, G. Mtare, E. Makuwe, H. Fritz // PLOS One. - 2013. - Vol. 8 (3). P. e59164. - DOI 10.1371/journal.pone.0059164.

97. Water for African elephants (Loxodonta africana): faecal microbial loads affect use of artificial waterholes / M. Ndlovu, A. Pérez-Rodríguez, E. Devereux, M. Thomas, A. Colina, L. Molaba // Biology Letters. - 2018. Vol. 14 (8). - P. 20180360. - DOI 10.1098/rsbl.2018.0360.

98. Stommel, C. Large mammals in Ruaha National Park, Tanzania, dig for water when water stops flowing and water bacterial load increases / C. Stommel, H. Hofer, M. Grobbel, M. L. East // Mammalian Biology. - 2016. Vol. 81 (1). - P. 21-30. - DOI 10.1016/j.mambio.2015.08.005.

99. Ramey, E. M. Desert-dwelling African elephants (Loxodonta africana) in Namibia dig wells to purify drinking water / E. M. Ramey, R. R. Ramey, L. M. Brown, S. T. Kelley // Pachyderm. - 2013. - Vol. 53. - P. 66-72.

100. Ssali, F. Damage to artificial seedlings across a disturbed Afromontane forest landscape / F. Ssali, S. R. Moe, D. Sheil // Biotropica. - 2019. - Vol. 2019 (5). - P. 652-663. - DOI 10.1111/btp.12703.

101. Obanda, V. Gastrointestinal parasites and associated pathological lesions in starving free-ranging African elephants / V. Obanda, T. Iwaki, N. M. Mutinda, F. Gakuya // African Journal of Wildlife Research. - 2011. - Vol. 41 (2). - P. 167-173. - DOI 10.3957/056.041.0203.

102. Kinsella, J. M. Endoparasites of African forest elephants (Loxodonta africana cyclotis) from the Republic of Congo and Central African Republic / J. M. Kinsella, S. L. Deem, S. Blake, A. S. Freeman // Comparative Parasitology. - 2004. - Vol. 71 (2). - P. 104-111. - DOI 10.1654/4131.

103. Baines, L. Occurrence and seasonality of internal parasite infection in elephants, Loxodonta africana, in the Okavango Delta, Botswana / L. Baines, E. R. Morgan, M. Ofthile, K. Evans // International Journal for Parasitology. 2015. - Vol. 4 (1). - P. 43-48. - DOI 10.1016/j.ijppaw.2015.01.004.

104. Vítovec, J. Fatal infection of an elephant calf caused by the trematode Protofasciola robusta (Lorenz, 1881) in Somaliland / J. Vítovec, B. Kotrlá, H. Haji, L. B. Hayles // Zentralblatt für Veterinärmedizin Reihe B. - 1984. Vol. 31 (1-10). - P. 597-602. - DOI 10.1111/j.1439-0450.1984.tb01340.x.

105. An outbreak of encephalomyocarditis-virus infection in free-ranging African elephants in the Kruger National Park / D. G. Grobler, J. P. Raath, L. E. Braack, D. F. Keet, G. H. Gerdes, B. J. Barnard, N. P. Kriek, J. Jardine, R. Swanepoel, L. Braack // Onderstepoort Journal of Veterinary Research. - 1995. - Vol. 62. - P. 97-108.

106. Van Sandwyk, J. H. d. T. Retrospective genetic characterisation of Encephalomyocarditis viruses from African elephant and swine recovers two distinct lineages in South Africa / J. H. d. T. van Sandwyk, N. C. Bennett, R. Swanepoel, A. D. S. Bastos // Veterinary Microbiology. - 2013. - Vol. 162 (1). - P. 23-31. - DOI 10.1016/j.vetmic.2012.08.008.

107. First reported case of fatal tuberculosis in a wild African elephant with past human-wildlife contact / V. Obanda, J. Poghon, M. Yongo, I. Mulei, M. Ngotho, K. Waititu, J. Makumi, F. Gakuya, P. Omondi, R. C. Soriguer, S. Alasaad // Epidemiology. - 2013. - Vol. 141 (7). - P. 1476-1480. - DOI 10.1017/S0950268813000022.

108. Fatal tuberculosis in a free-ranging African elephant and one health implications of human pathogens in wildlife / M. A. Miller, P. Buss, E. O. Roos, G. Hausler, A. Dippenaar, E. Mitchell, L. van Schalkwyk, S. RobbeAusterman, W. R. Waters, A. Sikar-Gang, K. P. Lyashchenko, S. D. C. Parsons, R. Warren, P. van Helden // Frontiers in Veterinary Science. - 2019. - Vol. 6. - P. 18. - DOI 10.3389/fvets.2019.00018.

109. Rothschild, B. M. Hyperdisease in the late Pleistocene: validation of an early 20th century hypothesis / B. M. Rothschild, R. Laub // Naturwissenschaften. - 2006. - Vol. 93 (11). - P. 557-564. - DOI 10.1007/s00114006-0144-8.

110. Leshchinskiy, S. V. Paleoecological investigation of mammoth remains from the Kraków Spadzista Street (B) site / S. V. Leshchinskiy // Quaternary International. - 2012. - Vol. 276. - P. 155-169. - DOI 10.1016/ j.quaint.2012.05.025

111. Power, R. J. Lion predation on elephants in the Savuti, Chobe national park, Botswana / J. Power, R. X. S. Compion // Journal of African Zoology. - 2009. - Vol. 44 (1). - P. 36-44. - DOI 10.3377/004.044.0104.

112. Salnicki, J. Spotted hyaenas Crocuta crocuta prey on new-born elephant calves in Hwange National Park, Zimbabwe / J. Salnicki, M. Teichmann, V. J. Wilson, F. Murindagomo // Koedoe. - 2001. - Vol. 44 (2). - P. $79-83$.

113. Loveridge, A. J. Influence of drought on predation of elephant (Loxodonta africana) calves by lions (Panthera leo) in an African wooded savannah / A. J. Loveridge, J. E. Hunt, F. Murindagomo, D. W. Macdonald // Journal of Zoology. - 2006. - Vol. 270 (3). - P. 523-530. - DOI 10.1111/j.1469-7998.2006.00181.x.

114. Prolonged drought results in starvation of African elephant (Loxodonta africana) / Y. A. Wato, I. M. A. Heitkönig, S. E. van Wieren, G. Wahungu, H. H. T. Prins, F. van Langevelde // Biological Conservation. - 2016. - Vol. 203. P. 89-96. - DOI 10.1016/j.biocon.2016.09.007.

115. The impact of large terrestrial carnivores on Pleistocene ecosystems / B. van Valkenburgh, M. W. Hayward, W. J. Ripple, C. Meloro, V. L. Roth // Proceedings of the National Academy of Sciences of the United States of America. - 2016. - Vol. 113 (4). - P. 862-867. - DOI 10.1073/pnas.1502554112.

116. The origins of $\mathrm{C}_{4}$ grasslands: Integrating evolutionary and ecosystem science / E. J. Edwards, C. P. Osborne, C. A. E. Strömberg, S. A. Smith, C 4 Grasses Consortium // Science. - 2010. - Vol. 328 (5978). - P. 587-591. DOI 10.1126/science.1177216.

117. Sage, R. The evolution of $C_{4}$ photosynthesis / R. Sage // New Phytologist. - 2004. - Vol. 161 (2). - P. 341-370. DOI 10.1111/j.1469-8137.2004.00974.x. 
118. $\mathrm{C}_{4}$ savanna grasses fail to maintain assimilation in drying soil under low $\mathrm{CO}_{2}$ compared with $\mathrm{C}_{3}$ trees despite lower leaf water demand / J. Quirk, C. Bellasio, D. A. Johnson, C. P. Osborne, D. J. Beerling // Functional Ecology. 2019. - Vol. 33 (3). - P. 388-398. - DOI 10.1111/1365-2435.13240.

119. Christin, P.-A. The evolutionary ecology of $\mathrm{C}_{4}$ plants / P.-A. Christin, C. P. Osborne // New Phytologist. - 2014.Vol. 204 (4). - P. 765-781. - DOI 10.1111/nph.13033.

120. Carbon isotopic signatures of soil organic matter correlate with leaf area index across woody biomes / B. Ladd, P. L. Peri, D. A. Pepper, L. C. R. Silva, D. Sheil, S. P. Bonser, S. W. Laffan, W. Amelung, A. Ekblad, P. Eliasson, H. Bahamonde, S. Duarte-Guardia, M. Bird // Journal of Ecology. - 2014. - Vol. 102 (6). - P. 1606-1611. DOI 10.1111/1365-2745.12309.

121. Woody cover and hominin environments in the past 6 million years / T. E. Cerling, J. G. Wynn, S. A. Andanje, M. I. Bird, D. K. Korir, N. E. Levin, W. Mace, A. N. Macharia, J. Quade, C. H. Remien // Nature. - 2011. Vol. 476. - P. 51-56. - DOI 10.1038/nature10306.

122. Stable isotope proxy records in tropical terrestrial environments / M. I. Bird, J. Haig, X. Hadeen, M. Rivera-Araya, C. M. Wurster, C. Zwart // Palaeogeography, Palaeoclimatology, Palaeoecology. - 2020. - Vol. 538. - P. 109445. DOI 10.1016/j.palaeo.2019.109445.

123. Tipple, B. J. The early origins of terrestrial $\mathrm{C}_{4}$ photosynthesis / B. J. Tipple, M. Pagani // Annual Review of Earth and Planetary Sciences. - 2007. - Vol. 35. - P. 435-461. - DOI 10.1146/annurev.earth.35.031306.140150.

124. Karp, A. T. Grassland fire ecology has roots in the late Miocene / A. T. Karp, A. K. Behrensmeyer, K. H. Freeman // Proceedings of the National Academy of Sciences of the United States of America. - 2018. - Vol. 115 (48). P. 12130-12135. - DOI 10.1073/pnas.1809758115.

125. Synchronous rise of African $\mathrm{C}_{4}$ ecosystems 10 million years ago in the absence of aridification / P. J. Polissar, C. Rose, K. T. Uno, S. R. Phelps, P. deMenocal // Nature Geoscience. - 2019. - Vol. 12 (8). P. 657-660. - DOI 10.1038/s41561-019-0399-2.

126. Retallack, G. J. Cenozoic expansion of grasslands and climatic cooling / G. J. Retallack // Journal of Geology. 2001. - Vol. 109 (4). - P. 407-426. - DOI 10.1086/320791.

127. Initial expansion of $\mathrm{C} 4$ vegetation in Australia during the late Pliocene / J. W. Andrae, F. A. McInerney, P. J. Polissar, J. M. K. Sniderman, S. Howard, P. A. Hall, S. R. Phelps // Geophysical Research Letters. - 2018. Vol. 45 (10). - P. 4831-4840. - DOI 10.1029/2018GL077833.

128. Madagascar's grasses and grasslands: anthropogenic or natural? / M. S. Vorontsova, G. Besnard, F. Forest, P. Malakasi, J. Moat, W. D. Clayton, P. Ficinski, G. M. Savva, O. P. Nanjarisoa, J. Razanatsoa, F. O. Randriatsara, J. M. Kimeu, W. R. Q. Luke, C. Kayombo, H. P. Linder // Proceedings of the Royal Society B: Biological Sciences. - 2016. - Vol. 283 (1823). - P. 20152262. - DOI 10.1098/rspb.2015.2262.

129. Crowley, B. E. A glance to the past: subfossils, stable isotopes, seed dispersal, and lemur species loss in southern Madagascar / B. E. Crowley, L. R. Godfrey, M. T. Irwin // American Journal of Primatology. - 2011. Vol. 73 (1). - P. 25-37. - DOI 10.1002/ajp.20817.

130. Using a surviving lineage of Madagascar's vanished megafauna for ecological restoration / M. Pedrono, O. L. Griffiths, A. Clausen, L. L. Smith, C. J. Griffiths, L. Wilmé, D. A. Burney // Biological Conservation. 2013. - Vol. 159. - P. 501-506. - DOI 10.1016/j.biocon.2012.11.027.

131. Atmosphere oxygen cycling through the Proterozoic and Phanerozoic / R. R. Large, I. Mukherjee, D. Gregory, J. Steadman, R. Corkrey, L. V. J. M. D. Danyushevsky // Mineralium Deposita. - 2019. - Vol. 54 (4). - P. 485-506. DOI 10.1007/s00126-019-00873-9.

132. Scott, A. C. The diversification of Paleozoic fire systems and fluctuations in atmospheric oxygen concentration / A. C. Scott, I. J. Glasspool // Proceedings of the National Academy of Sciences of the United States of America. 2006. - Vol. 103 (29). - P. 10861-10865. - DOI 10.1073/pnas.0604090103.

133. Glasspool, I. J. Charcoal in the Silurian as evidence for the earliest wildfire / I. J. Glasspool, D. Edwards, L. Axe // Geology. - 2004. - Vol. 32 (5). - P. 381-383. - DOI 10.1130/G20363.1.

134. Liu, Z. Evidence of wildfires and elevated atmospheric oxygen at the Frasnian-Famennian boundary in New York (USA): Implications for the Late Devonian mass extinction / Z. Liu, D. Selby, P. C. Hackley, D. J. Over // GSA Bulletin. - 2020. - Vol. 132 (9-10). - P. 2043-2054. - DOI 10.1130/B35457.1.

135. Meyer-Berthaud, B. Archaeopteris is the earliest known modern tree / B. Meyer-Berthaud, S. E. Scheckler, J. Wendt // Nature. - 1999. - Vol. 398 (6729). - P. 700-701. - DOI 10.1038/19516.

136. Cressler, W. L. Evidence of earliest known wildfires / W. L. Cressler III // Palaios. - 2001. - Vol. 16 (2). P. 171-174. - DOI 10.2307/3515528.

137. Ward, P. Confirmation of Romer's Gap as a low oxygen interval constraining the timing of initial arthropod and vertebrate terrestrialization / P. Ward, C. Labandeira, M. Laurin, R. A. Berner // Proceedings of the National Academy of Sciences of the United States of America. - 2006. - Vol. 103 (45). - P. 16818-16822. DOI 10.1073/pnas.0607824103.

138. Phanerozoic atmospheric oxygen / R. A. Berner, D. J. Beerling, R. Dudley, J. M. Robinson, R. A. Wildman Jr. // Annual Review of Earth and Planetary Sciences. - 2003. - Vol. 31 (1). - P. 105-134. - DOI 10.1146/annurev.earth.31.100901.141329.

139. Nelson, M. I. A dynamical systems model of the limiting oxygen index test: II. Retardancy due to char formation and addition of inert fillers / M. I. Nelson // Combustion Theory and Modelling. - 2001. - Vol. 5 (1). - P. 59-83. DOI 10.1088/1364-7830/5/1/304. 
140. Falcon-Lang, H. J. Fire ecology of the Carboniferous tropical zone / H. J. Falcon-Lang // Palaeogeography Palaeoclimatology Palaeoecology. - 2000. - Vol. 164 (1-4). - P. 339-355. - DOI 10.1016/S0031-0182(00)00193-0.

141. Falcon-Lang, H. J. Pennsylvanian uplands were forested by giant cordaitalean trees / H. J. Falcon-Lang, A. R. Bashforth // Geology. - 2004. - Vol. 32 (5). - P. 417-420. - DOI 10.1130/G20371.1.

142. He, T. A 350-million-year legacy of fire adaptation among conifers / T. He, C. M. Belcher, B. B. Lamont, S. L. Lim // Journal of Ecology. - 2016. - Vol. 104 (2). - P. 352-363. - DOI 10.1111/1365-2745.12513.

143. Hernandez-Castillo, G. R. Reconstruction of the Pennsylvanian-age walchian conifer Emporia cryptica sp. nov. (Emporiaceae: Voltziales) / G. R. Hernandez-Castillo, R. A. Stockey, G. W. Rothwell, G. Mapes // Review of Palaeobotany. - 2009. - Vol. 157 (3-4). - P. 218-237. - DOI 10.1016/j.revpalbo.2009.05.003.

144. The evolutionary history of termites as inferred from 66 mitochondrial genomes / T. Bourguignon, N. Lo, S. L. Cameron, J. Šobotník, Y. Hayashi, S. Shigenobu, D. Watanabe, Y. Roisin, T. Miura, T. A. Evans // Molecular Biology and Evolution. - 2014. - Vol. 32 (2). - P. 406-421. - DOI 10.1093/molbev/msu308.

145. He, T. Baptism by fire: the pivotal role of ancient conflagrations in evolution of the Earth's flora / T. He, B. B. Lamont // National Science Review. - 2017. - Vol. 5 (2). - P. 237-254. - DOI 10.1093/nsr/nwx041.

146. Sahney, S. Rainforest collapse triggered Carboniferous tetrapod diversification in Euramerica / S. Sahney, M. J. Benton, H. J. Falcon-Lang // Geology. - 2010. - Vol. 38 (12). - P. 1079-1082. - DOI 10.1130/G31182.1.

147. Lamont, B. B. Evolutionary history of fire-stimulated resprouting, flowering, seed release and germination / B. B. Lamont, T. He, Z. Yan // Biological Reviews. - 2019. - Vol. 94 (3). - P. 903-928. - DOI 10.1111/brv.12483.

148. Bowman, D. M. J. S. Have plants evolved to self-immolate? / D. M. J. S. Bowman, B. J. French, L. D. Prior // Frontiers in Plant Science. - 2014. - Vol. 5. - P. 590. - DOI 10.3389/fpls.2014.00590.

149. Pausas, J. G. Flammability as an ecological and evolutionary driver / J. G. Pausas, J. E. Keeley, D. W. Schwilk // Journal of Ecology. - 2017. - Vol. 105 (2). - P. 289-297. - DOI 10.1111/1365-2745.12691.

150. Zavada, M. S. Plant-animal interaction: The effect of Permian megaherbivores on the glossopterid flora / M. S. Zavada, M. T. Mentis // American Midland Naturalist. - 1992. - Vol. 127 (1). - P. 1-12. - DOI 10.2307/2426316.

151. Williams, V. S. Quantitative analysis of dental microwear in hadrosaurid dinosaurs, and the implications for hypotheses of jaw mechanics and feeding / V. S. Williams, P. M. Barrett, M. A. Purnell // Proceedings of the National Academy of Sciences of the United States of America. - 2009. - Vol. 106 (27). - P. 11194-11199. - DOI 10.1073/pnas.0812631106.

152. Mallon, J. C. The functional and palaeoecological implications of tooth morphology and wear for the megaherbivorous dinosaurs from the dinosaur park formation (Upper Campanian) of Alberta, Canada / J. C. Mallon, J. S. Anderson // PLOS ONE. - 2014. - Vol. 9 (6). - P. e98605. - DOI 10.1371/journal.pone.0098605.

153. Bajdek, P. Putative dicynodont coprolites from the Upper Triassic of Poland / P. Bajdek, K. Owocki, G. Niedźwiedzki // Palaeogeography, Palaeoclimatology, Palaeoecology. - 2014. - Vol. 411. - P. 1-17. DOI 10.1016/j.palaeo.2014.06.013.

154. Chin, K. The paleobiological implications of herbivorous dinosaur coprolites from the Upper Cretaceous Two Medicine Formation of Montana: why eat wood? / K. Chin // Palaios. - 2007. - Vol. 22 (5). - P. 554-566. DOI 10.2307/27670451.

155. Baghai-Riding, N. L. An unusual dinosaur coprolite from the Campanian Aguja Formation, Texas / N. L. BaghaiRiding, J. N. DiBenedetto // Gulf Coast Association of Geological Societies Transactions. - 2001. - Vol. 51. P. 9-20. - DOI 10.1306/8626CE33-173B-11D7-8645000102C1865D.

156. Tiffney, B. H. The role of vertebrate herbivory in the evolution of land plants / B. H. Tiffney // The Paleobotanist. 1992. - Vol. 41. - P. 87-97.

157. Saarinen, J. The palaeontology of browsing and grazing / J. Saarinen // The Ecology of Browsing and Grazing II / ed. by I. J. Gordon, H. H. T. Prins. - Cham, Switzerland : Springer, 2019. - P. 5-59.

158. Spiny plants, mammal browsers, and the origin of African savannas / T. Charles-Dominique, T. J. Davies, G. P. Hempson, B. S. Bezeng, B. H. Daru, R. M. Kabongo, O. Maurin, A. M. Muasya, M. van der Bank, W. J. Bond // Proceedings of the National Academy of Sciences of the United States of America. - 2016. Vol. 113 (38). - P. E5572-E5579. - DOI 10.1073/pnas.1607493113.

159. Dinosaurs and land plants / M. Coe, D. Dilcher, J. Farlow, O. Jarzen, D. Russell // The origin of angiosperms and their biological consequences, ed. E. Friis, W. Chaloner, P. Crane. - Cambridge, UK : Cambridge University Press, 1987. - P. 225-258.

160. Royo, A. A. On the formation of dense understory layers in forests worldwide: consequences and implications for forest dynamics, biodiversity, and succession / A. A. Royo, W. P. Carson // Canadian Journal of Forest ResearchRevue Canadienne De Recherche Forestiere. - 2006. - Vol. 36 (6). - P. 1345-1362. - DOI 10.1139/x06-025.

161. George, L. O. The fern understory as an ecological filter: emergence and establishment of canopy-tree seedlings / L. O. George, F. A. Bazzaz // Ecology. - 1999. - Vol. 80 (3). - P. 833-845. - DOI 10.1890/00129658(1999)080[0833:TFUAAE]2.0.CO;2.

162. Marrs, R. H. Biological flora of the British Isles: Pteridium aquilinum (L.) Kuhn / R. H. Marrs, A. S. Watt // Journal of Ecology. - 2006. - Vol. 94 (6). - P. 1272-1321. - DOI 10.1111/j.1365-2745.2006.01177.x.

163. Ssali, F. A first look at the impediments to forest recovery in bracken-dominated clearings in the African Highlands / F. Ssali, S. R. Moe, D. Sheil // Forest Ecology and Management. - 2017. - Vol. 402. - P. 166-176. DOI 10.1016/j.foreco.2017.07.050. 
164. Ssali, F. Tree seed rain and seed removal, but not the seed bank, impede forest recovery in bracken (Pteridium aquilinum (L.) Kuhn)-dominated clearings in the African highlands / F. Ssali, S. R. Moe, D. Sheil // Ecology and Evolution. - 2018. - Vol. 8 (8). - P. 4224-4236. - DOI 10.1002/ece3.3944.

165. Ssali, F. The differential effects of bracken (Pteridium aquilinum (L.) Kuhn) on germination and seedling performance of tree species in the African tropics / F. Ssali, S. R. Moe, D. Sheil // Plant Ecology. - 2019. - Vol. 220 (1). P. 41-55. - DOI 10.1007/s11258-018-0901-8.

166. Masozera, A. Regeneration of burned forested areas with periodic removal of Pteridium aquilinum (L.) Kuhn. ferns, Nyungwe National Park, Rwanda / A. Masozera // Unpublished Report. - Bronx Zoo, New York, USA : Wildlife Conservation Society, 2004.

167. Late Miocene global cooling and the rise of modern ecosystems / T. D. Herbert, K. T. Lawrence, A. Tzanova, L. C. Peterson, R. Caballero-Gill, C. S. Kelly // Nature Geoscience. - 2016. - Vol. 9 (11). - P. 843-847. DOI 10.1038/ngeo2813.

168. Bobe, R. The evolution of arid ecosystems in eastern Africa / R. Bobe // Journal of Arid Environments. - 2006. Vol. 66 (3). - P. 564-584. - DOI 10.1016/j.jaridenv.2006.01.010.

169. Global grass (Poaceae) success underpinned by traits facilitating colonization, persistence and habitat transformation / H. P. Linder, C. E. R. Lehmann, S. Archibald, C. P. Osborne, D. M. Richardson // Biological Reviews. 2018. - Vol. 93 (2). - P. 1125-1144. - DOI 10.1111/brv.12388.

170. Beerling, D. J. The origin of the savanna biome / D. J. Beerling, C. P. Osborne // Global Change Biology. - 2006. Vol. 12 (11). - P. 2023-2031. - DOI 10.1111/j.1365-2486.2006.01239.x.

171. Boers, N. A deforestation-induced tipping point for the South American monsoon system / N. Boers, N. Marwan, H. M. J. Barbosa, J. Kurths // Scientific Reports. - 2017. - Vol. 7. - P. 41489. - DOI 10.1038/srep41489.

172. Makarieva, A. M. Biotic pump of atmospheric moisture as driver of the hydrological cycle on land / A. M. Makarieva, V. G. Gorshkov // Hydrology and Earth System Sciences. - 2007. - Vol. 11 (2). - P. 1013-1033. DOI 10.5194/hess-11-1013-2007.

173. Lawrence, D. Effects of tropical deforestation on climate and agriculture / D. Lawrence, K. Vandecar // Nature Climate Change. - 2015. - Vol. 5 (1). - P. 27-36. - DOI 10.1038/nclimate2430.

174. Persistence of soil organic matter as an ecosystem property / M. W. Schmidt, M. S. Torn, S. Abiven, T. Dittmar, G. Guggenberger, I. A. Janssens, M. Kleber, I. Kögel-Knabner, J. Lehmann, D. A. C. Manning, P. Nannipieri, D. P. Rasse, S. Weiner, S. E. Trumbore // Nature. - 2011. - Vol. 478 (7367). - P. 49. - DOI 10.1038/nature10386.

175. Maslin, M. Forty years of linking orbits to ice ages / M. Maslin // Nature. - 2016. - Vol. 540 (7632). - P. 208-209. DOI 10.1038/540208a.

176. Hoag, C. African environmental change from the Pleistocene to the Anthropocene / C. Hoag, J.-C. Svenning // Annual Review of Environment and Resources. - 2017. - Vol. 42. - P. 27-54. - DOI 10.1146/annurev-environ102016-060653.

177. Maley, J. The African rain forest - main characteristics of changes in vegetation and climate from the Upper Cretaceous to the Quaternary / J. Maley // Proceedings of the Royal Society of Edinburgh, Section B: Biological Sciences. - 1996. - Vol. 104. - P. 31-73. - DOI 10.1017/S0269727000006114.

178. Dupont, L. M. Effects of atmospheric $\mathrm{CO}_{2}$ variability of the past $800 \mathrm{kyr}$ on the biomes of Southeast Africa / L. M. Dupont, T. Caley, I. S. Castañeda // Climate of the Past. - 2019. - Vol. 15 (3). - P. 1083-1097. - DOI 10.5194/cp-15-1083-2019.

179. Neotropical forest expansion during the last glacial period challenges refuge hypothesis / Y. L. R. Leite, L. P. Costa, A. C. Loss, R. G. Rocha, H. Batalha-Filho, A. C. Bastos, V. S. Quaresma, V. Fagundes, R. Paresque, M. Passamani, R. Pardini // Proceedings of the National Academy of Sciences of the United States of America. - 2016. Vol. 113 (4). - P. 1008-1013. - DOI 10.1073/pnas.1513062113.

180. Jones, M. W. Global fire emissions buffered by the production of pyrogenic carbon / M. W. Jones, C. Santín, G. R. van der Werf, S. H. Doerr // Nature Geoscience. - 2019. - Vol. 12 (9). - P. 742-747. - DOI 10.1038/ s41561-019-0403-x.

181. Berner, R. A. Oxygen and evolution / R. A. Berner, J. M. VandenBrooks, P. D. Ward // Science. - 2007. Vol. 316 (5824). - P. 557-558. - DOI 10.1126/science.1140273.

182. Sherwood, S. C. Tropospheric water vapor, convection, and climate / S. C. Sherwood, R. Roca, T. M. Weckwerth, N. G. Andronova // Reviews of Geophysics. - 2010. - Vol. 48 (2). - DOI 10.1029/2009rg000301.

183. Kinetic energy generation in heat engines and heat pumps: the relationship between surface pressure, temperature and circulation cell size / A. M. Makarieva, V. G. Gorshkov, A. V. Nefiodov, D. Sheil, A. D. Nobre, P. Shearman, B.-L. Li // Tellus A: Dynamic Meteorology and Oceanography. - 2017. - Vol. 69 (1). - P. 1272752. DOI 10.1080/16000870.2016.1272752.

184. Hill, S. A. Theories for past and future monsoon rainfall changes / S. A. Hill // Current Climate Change Reports. 2019. - Vol. 5 (3). - P. 160-171. - DOI 10.1007/s40641-019-00137-8.

185. Vegetation cover of Brazil in the last $21 \mathrm{ka}$ : New insights into the Amazonian refugia and Pleistocenic arc hypotheses / D. M. Arruda, C. E. G. R. Schaefer, R. S. Fonseca, R. R. C. Solar, E. I. Fernandes-Filho // Global Ecology and Biogeography. - 2018. - Vol. 27 (1). - P. 47-56. - DOI 10.1111/geb.12646.

186. Ivory, S. J. Climate, herbivory, and fire controls on tropical African forest for the last $60 \mathrm{ka} / \mathrm{S}$. J. Ivory, J. Russell // Quaternary Science Reviews. - 2016. - Vol. 148. - P. 101-114. - DOI 10.1016/j.quascirev.2016.07.015. 
187. Pleistocene megafaunal collapse, novel plant communities, and enhanced fire regimes in North America / J. L. Gill, J. W. Williams, S. T. Jackson, K. B. Lininger, G. S. Robinson // Science. - 2009. - Vol. 326 (5956). P. 1100-1103. - DOI 10.1126/science.1179504.

188. Climatic and megaherbivory controls on late-glacial vegetation dynamics: a new, high-resolution, multi-proxy record from Silver Lake, Ohio / J. L. Gill, J. W. Williams, S. T. Jackson, J. P. Donnelly, G. C. Schellinger // Quaternary Science Reviews. - 2012. - Vol. 34. - P. 66-80. - DOI 10.1016/j.quascirev.2011.12.008.

189. Doughty, C. E. Biophysical feedbacks between the Pleistocene megafauna extinction and climate: The first human-induced global warming? / C. E. Doughty, A. Wolf, C. B. Field // Geophysical Research Letters. - 2010. Vol. 37 (15). - P. L15703. - DOI 10.1029/2010g1043985.

190. Ecological thresholds at the savanna-forest boundary: how plant traits, resources and fire govern the distribution of tropical biomes / W. A. Hoffmann, E. L. Geiger, S. G. Gotsch, D. R. Rossatto, L. C. R. Silva, O. L. Lau, M. Haridasan, A. C. Franco // Ecology Letters. - 2012. - Vol. 15 (7). - P. 759-768. - DOI 10.1111/j.14610248.2012.01789.x.

191. Determinants of woody cover in African savannas / M. Sankaran, N. P. Hanan, R. J. Scholes, J. Ratnam, D. J. Augustine, B. S. Cade, J. Gignoux, S. I. Higgins, X. Le Roux, F. Ludwig, J. Ardo, F. Banyikwa, A. Bronn, G. Bucini, K. K. Caylor, M. B. Coughenour, A. Diouf, W. Ekaya, C. J. Feral, E. C. February, P. G. H. Frost, P. Hiernaux, H. Hrabar, K. L. Metzger, H. H. T. Prins, S. Ringrose, W. Sea, J. Tews, J. Worden, N. Zambatis // Nature. - 2005. Vol. 438 (7069). - P. 846-849. - DOI 10.1038/nature04070.

192. Pausas, J. G. Alternative biome states in terrestrial ecosystems / J. G. Pausas, W. J. Bond // Trends in Plant Science. - 2020. - Vol. 25 (3). - P. 250-263. - DOI 10.1016/j.tplants.2019.11.003.

193. Wilcox, B. P. Emerging frameworks for understanding and mitigating woody plant encroachment in grassy biomes / B. P. Wilcox, A. Birt, S. D. Fuhlendorf, S. R. Archer // Current Opinion in Environmental Sustainability. 2018. - Vol. 32. - P. 46-52. - DOI 10.1016/j.cosust.2018.04.005.

194. Bond, W. J. The global distribution of ecosystems in a world without fire / W. J. Bond, F. I. Woodward, G. F. Midgley // New Phytologist. - 2005. - Vol. 165 (2). - P. 525-537. - DOI 10.1111/j.1469-8137.2004.01252.x.

195. Archibald, S. A unified framework for plant life-history strategies shaped by fire and herbivory / S. Archibald, G. P. Hempson, C. Lehmann // New Phytologist. - 2019. - Vol. 224 (4). - P. 1490-1503. - DOI 10.1111/nph.15986.

196. Midgley, J. J. Flammability is not selected for, it emerges / J. J. Midgley // Australian Journal of Botany. - 2013. Vol. 61 (2). - P. 102-106. - DOI 10.1071/BT12289.

197. Mutch, R. W. Wildland fires and ecosystems - A hypothesis / R. W. Mutch // Ecology. - 1970. - Vol. 51 (6). P. 1046-1051. - DOI 10.2307/1933631.

198. Snyder, J. R. The role of fire: Mutch ado about nothing? / J. R. Snyder // Oikos. - 1984. - P. 404-405.

199. Does pyrogenicity protect burning plants? / P. R. Gagnon, H. A. Passmore, W. J. Platt, J. A. Myers, C. E. T. Paine, K. E. Harms // Ecology. - 2010. - Vol. 91 (12). - P. 3481-3486. - DOI 10.1890/10-0291.1.

200. Schertzer, E. Fire spread and the issue of community-level selection in the evolution of flammability / E. Schertzer, A. C. Staver // Journal of the Royal Society Interface. - 2018. - Vol. 15 (147). - P. 20180444. DOI 10.1098/rsif.2018.0444.

201. Uyehara, I. K. The role of succession in the evolution of flammability / I. K. Uyehara, S. W. Pacala // Theoretical Ecology. - 2018. - Vol. 11 (3). - P. 291-303. - DOI 10.1007/s12080-018-0366-3.

202. Pausas, J. G. Bark thickness and fire regime / J. G. Pausas // Journal of Functional Ecology. - 2015. - Vol. 29 (3). P. 315-327. - DOI 10.1111/1365-2435.12372.

203. Convergence of bark investment according to fire and climate structures ecosystem vulnerability to future change / A. F. A. Pellegrini, W. R. L. Anderegg, C. E. T. Paine, W. A. Hoffmann, T. Kartzinel, S. S. Rabin, D. Sheil, A. C. Franco, S. W. Pacala // Ecology Letters. - 2017. - Vol. 20 (3). - P. 307-316. - DOI 10.1111/ele.12725.

204. Bond, W. J. A proposed $\mathrm{CO}_{2}$-controlled mechanism of woody plant invasion in grasslands and savannas / W. J. Bond, G. F. Midgley // Global Change Biology. - 2000. - Vol. 6 (8). - P. 865-869. - DOI 10.1046/j.13652486.2000.00365.x.

205. Stevens, N. Transplant experiments point to fire regime as limiting savanna tree distribution / N. Stevens, S. A. Archibald, W. J. Bond // Frontiers in Ecology and Evolution. - 2018. - Vol. 6. - P. 137. - DOI 10.3389/fevo.2018.00137.

206. Archibald, S. What limits fire? An examination of drivers of burnt area in Southern Africa / S. Archibald, D. P. Roy, B. W. van Wilgen, R. J. Scholes // Global Change Biology. - 2009. - Vol. 15 (3). - P. 613-630. DOI $10.1111 / \mathrm{j} .1365-2486.2008 .01754 . x$.

207. Eggeling, W. J. Observations on the ecology of the Budongo Rain Forest, Uganda / W. J. Eggeling // Journal of Ecology. - 1947. - Vol. 34 (1). - P. 20-87. - DOI 10.2307/2256760.

208. Sheil, D. Long-term observations of rain forest succession, tree diversity and responses to disturbance / D. Sheil // Plant Ecology. - 2001. - Vol. 155 (2). - P. 183-199. - DOI 10.1023/A:1013243411819.

209. Van Nieuwstadt, M. G. L. Drought, fire and tree survival in a Borneo rain forest, East Kalimantan, Indonesia / M. G. L. Nieuwstadt, D. Sheil // Journal of Ecology. - 2005. - Vol. 93 (1). - P. 191-201. - DOI 10.1111/j.13652745.2004.00954.x.

210. Cochrane, M. A. Fire science for rainforests / M. A. Cochrane // Nature. - 2003. - Vol. 421 (6926). - P. 913-919. DOI $10.1038 /$ nature 01437 . 
211. Brookfield, H. In Place of the Forest: Environmental and Socio-economic Transformations in Borneo and the Eastern Malay Peninsula / H. Brookfield, L. Potter, Y. Byron // Tokyo, Japan : United Nations University Press, 1995. $-310 \mathrm{p}$.

212. Goldammer, J. G. Natural rain forest fires in Eastern Borneo during the Pleistocene and Holocene / J. G. Goldammer, B. Seibert // Naturwissenschaften. - 1989. - Vol. 76 (11). - P. 518-520. - DOI 10.1007/BF00374124.

213. The "cultured rainforests" of Borneo / G. Barker, C. Hunt, H. Barton, C. Gosden, S. Jones, L. Lloyd-Smith, L. Farr, B. Nyirí, S. O'Donnell // Quaternary International. - 2017. - Vol. 448. - P. 44-61. - DOI 10.1016/ j.quaint.2016.08.018.

214. Do anthropogenic dark earths occur in the interior of Borneo? Some initial observations from East Kalimantan / D. Sheil, I. Basuki, L. German, T. W. Kuyper, G. Limberg, R. K. Puri, B. Sellato, M. Van Noordwijk, E. Wollenberg // Forests. - 2012. - Vol. 3 (2). - P. 207-229. - DOI 10.3390/f3020207.

215. Hammond, D. S. Upland soil charcoal in the wet tropical forests of Central Guyana / D. S. Hammond, H. ter Steege, K. van der Borg // Biotropica. - 2007. - Vol. 39 (2). - P. 153-160. - DOI 10.1111/j.1744-7429.2006.00257.x.

216. Holocene fire and occupation in Amazonia: records from two lake districts / M. B. Bush, M. R. Silman, M. B. de Toledo, C. Listopad, W. D. Gosling, C. Williams, P. E. de Oliveira, C. Krisel // Philosophical Transactions of the Royal Society B. - 2007. - Vol. 362 (1478). - P. 209-218. - DOI 10.1098/rstb.2006.1980.

217. Palaeofires in Amazon: Interplay between land use change and palaeoclimatic events / R. C. Cordeiro, B. Turcq, L. S. Moreira, R. de A. R. Rodrigues, F. F. Lamego Simões Filho, G. S. Martins, A. B. Santos, M. Barbosa, M. C. Guilles da Conceição, R. da C. Rodrigues, H. Evangelista, P. Moreira-Turcq, Y. P. Penido, A. Sifeddine, J. C. S. Seoane // Palaeogeography, Palaeoclimatology, Palaeoecology. - 2014. - Vol. 415. - P. 137-151. DOI 10.1016/j.palaeo.2014.07.020.

218. Makarieva, A. M. The biotic pump: Condensation, atmospheric dynamics and climate / A. M. Makarieva, V. G. Gorshkov // International Journal of Water. - 2010. - Vol. 5 (4). - P. 365-385. - DOI 10.1504/ IJW.2010.038729.

219. Sheil, D. How forests attract rain: An examination of a new hypothesis / D. Sheil, D. Murdiyarso // Bioscience. 2009. - Vol. 59 (4). - P. 341-347. - DOI 10.1525/bio.2009.59.4.12.

220. Laurance, W. F. Positive feedbacks among forest fragmentation, drought, and climate change in the Amazon / W. F. Laurance, G. B. Williamson // Conservation Biology. - 2001. - Vol. 15 (6). - P. 1529-1535. DOI 10.1046/j.1523-1739.2001.01093.x.

221. Edwards, H. G. M. Will-o'-the-Wisp: an ancient mystery with extremophile origins? / H. G. M. Edwards // Proceedings of the Royal Society A: Mathematical, Physical and Engineering Sciences. - 2014. - Vol. 372 (2030). P. 20140206. - DOI 10.1098/rsta.2014.0206.

222. Restuccia, F. Self-ignition of natural fuels: Can wildfires of carbon-rich soil start by self-heating? / F. Restuccia, X. Huang, G. Rein // Fire Safety Journal. - 2017. - Vol. 91. - P. 828-834. - DOI 10.1016/j.firesaf.2017.03.052.

223. Pechony, O. Driving forces of global wildfires over the past millennium and the forthcoming century $/$ O. Pechony, D. T. Shindell // Proceedings of the National Academy of Sciences of the United States of America. 2010. - Vol. 107 (45). - P. 19167-19170. - DOI 10.1073/pnas.1003669107.

224. Implications of changing climate for global wildland fire / M. D. Flannigan, M. A. Krawchuk, W. J. de Groot, B. M. Wotton, L. M. Gowman // J International Journal of Wildland Fire. - 2009. - Vol. 18 (5). - P. 483-507. DOI 10.1071/WF08187.

225. Singh, R. V. K. Spontaneous heating and fire in coal mines / R. V. K. Singh // Procedia Engineering. - 2013. Vol. 62. - P. 78-90. - DOI 10.1016/j.proeng.2013.08.046.

226. Fredriksson, G. Extinguishing the 1998 forest fires and subsequent coal fires in the Sungai Wain Protection Forest, East Kalimantan, Indonesia / G. Fredrikkson // Communities in flames: Proceedings of an international conference on community involvement in fire management. - Bangkok, Thailand : FAO and FireFight SE Asia, 2002.

227. Whitehouse, A. E. Coal fires in Indonesia / A. E. Whitehouse, A. A. S. Mulyana // International Journal of Coal Geology. - 2004. - Vol. 59 (1-2). - P. 91-97. - DOI 10.1016/j.coal.2003.08.010.

228. Can trophic rewilding reduce the impact of fire in a more flammable world? / C. N. Johnson, L. D. Prior, S. Archibald, H. M. Poulos, A. M. Barton, G. J. Williamson, D. M. J. S. Bowman // Philosophical Transactions of the Royal Society B: Biological Sciences. - 2018. - Vol. 373 (1761). - P. 20170443. - DOI 10.1098/rstb.2017.0443.

229. Effects of fire and herbivory on the stability of savanna ecosystems / F. Van Langevelde, C. A. D. M. Van De Vijver, L. Kumar, J. Van De Koppel, N. De Ridder, J. Van Andel, A. K. Skidmore, J. W. Hearne, L. Stroosnijder, W. J. Bond, H. H. T. Prins, M. Rietkerk // Ecology. - 2003. - Vol. 84 (2). - P. 337-350. - DOI 10.1890/00129658(2003)084[0337:EOFAHO]2.0.CO;2.

230. The Ecology of Browsing and Grazing II / ed. by I. J. Gordon, H. H. T. Prinss. - Springer, 2019. - 451 p.

231. Animals as agents in fire regimes / C. N. Foster, S. C. Banks, G. J. Cary, C. N. Johnson, D. B. Lindenmayer, L. E. Valentine // Trends in Ecology \& Evolution. - 2020. - Vol. 35 (4). - P. 346-356. DOI 10.1016/j.tree.2020.01.002.

232. Comparing seed removal rates in actively and passively restored tropical moist forests / E. Ssekuubwa, L. E. Loe, D. Sheil, M. Tweheyo, S. R. Moe // Restoration Ecology. - 2018. - Vol. 26 (4). - P. 720-728. - DOI 10.1111/ rec. 12629. 
233. Ickes, K. Effects of native pigs (Sus scrofa) on woody understorey vegetation in a Malaysian lowland rain forest / K. Ickes, S. J. DeWalt, S. Appanah // Journal of Tropical Ecology. - 2001. - Vol. 17 (2). - P. 191-206. DOI 10.1017/S0266467401001134.

234. Barrios-Garcia, M. N. Impact of wild boar (Sus scrofa) in its introduced and native range: a review / M. N. Barrios-Garcia, S. A. Ballari // Biological Invasions. - 2012. - Vol. 14 (11). - P. 2283-2300. - DOI 10.1007/s10530012-0229-6.

235. Impact of El Niño and logging on canopy tree recruitment in Borneo / L. M. Curran, I. Caniago, G. D. Paoli, D. Astianti, M. Kusneti, M. Leighton, C. E. Nirarita, H. Haeruman // Science. - 1999. - Vol. 286 (5447). P. 2184-2188. - DOI 10.1126/science.286.5447.2184.

236. Moe, S. R. What controls woodland regeneration after elephants have killed the big trees? / S. R. Moe, L. P. Rutina, H. Hytteborn, J. T. Du Toit // Journal of Applied Ecology. - 2009. - Vol. 46 (1). - P. 223-230. DOI 10.1111/j.1365-2664.2008.01595.x.

237. Intentional fire-spreading by "Firehawk" raptors in Northern Australia / M. Bonta, R. Gosford, D. Eussen, N. Ferguson, E. Loveless, M. Witwer // Journal of Ethnobiology. - 2017. - Vol. 37 (4). - P. 700-719. - DOI 10.2993/ 0278-0771-37.4.700.

238. Coghlan, A. The birds that steal fire (Arsonist falcons suggest birds discovered fire before humans did) / A. Coghlan // New Scientist. - 2018. - Vol. 237 (4).

239. Augustine, D. J. Regulation of shrub dynamics by native browsing ungulates on East African rangeland / D. J. Augustine, S. J. McNaughton // Journal of Applied Ecology. - 2004. - Vol. 41 (1). - P. 45-58. DOI 10.1111/j.1365-2664.2004.00864.x.

240. Browsing and fire interact to suppress tree density in an African savanna / A. C. Staver, W. J. Bond, W. D. Stock, S. J. van Rensburg, M. S. Waldram // Ecological Applications. - 2009. - Vol. 19 (7). - P. 1909-1919. DOI 10.1890/08-1907.1.

241. Tree resprout dynamics following fire depend on herbivory by wild ungulate herbivores / E. M. LaMalfa, D. M. Kimuyu, R. L. Sensenig, T. P. Young, C. Riginos, K. E. Veblen // Journal of Ecology. - 2019. - Vol. 107 (5). P. 2493-2502. - DOI 10.1111/1365-2745.13186.

242. Ecology of grazing lawns in Africa / G. P. Hempson, S. Archibald, W. J. Bond, R. P. Ellis, C. C. Grant, F. J. Kruger, L. M. Kruger, C. Moxley, N. Owen-Smith, M. J. S. Peel, K. J. Vickers // Biological Reviews. - 2015. Vol. 90 (3). - P. 979-994. - DOI 10.1111/brv.12145.

243. A disease-mediated trophic cascade in the Serengeti and its implications for ecosystem C / R. M. Holdo, A. R. E. Sinclair, A. P. Dobson, K. L. Metzger, B. M. Bolker, M. E. Ritchie, R. D. Holt // PLOS Biology. - 2009. Vol. 7 (9). - P. e1000210. - DOI 10.1371/journal.pbio.1000210.

244. Prins, H. H. T. Herbivore population crashes and woodland structure in East Africa / H. H. T. Prins, H. P. van der Jeugd // Journal of Ecology. - 1993. - P. 305-314. - DOI 10.2307/2261500.

245. Bowman, D. M. J. S. Using carbon isotope analysis of the diet of two introduced Australian megaherbivores to understand Pleistocene megafaunal extinctions / D. M. J. S. Bowman, B. P. Murphy, C. R. McMahon // Journal of Biogeography. - 2010. - Vol. 37 (3). - P. 499-505. - DOI 10.1111/j.1365-2699.2009.02206.x.

246. Murphy, B. P. What controls the distribution of tropical forest and savanna? / B. P. Murphy, D. M. J. S. Bowman // Ecology Letters. - 2012. - Vol. 15 (7). - P. 748-758. - DOI 10.1111/j.1461-0248.2012.01771.x.

247. Distribution and determinants of savannas / S. Archibald, W. J. Bond, W. Hoffmann, C. Lehmann, C. Staver, N. Stevens // Savanna and Woody Plants Large Herbivores / ed. by P. F. Scogings, M. Sankaran. - 2019. P. 1-24. - DOI 10.1002/9781119081111.ch1.

248. Sheil, D. Developing tests of successional hypotheses with size-structured populations, and an assessment using long-term data from a Ugandan rain forest / D. Sheil // Plant Ecology. - 1999. - Vol. 140 (1). - P. 117-127. - DOI 10.1023/A:1009729108668.

249. The megabiota are disproportionately important for biosphere functioning / B. J. Enquist, A. J. Abraham, M. B. J. Harfoot, Y. Malhi, C. E. Doughty // Nature Communications. - 2020. - Vol. 11 (1). - P. 699. DOI 10.1038/s41467-020-14369-y.

250. Haynes, G. Elephants (and extinct relatives) as earth-movers and ecosystem engineers / G. Haynes // Geomorphology. - 2012. - Vol. 157-158. - P. 99-107. - DOI 10.1016/j.geomorph.2011.04.045.

251. Arsenault, R. Facilitation versus competition in grazing herbivore assemblages / R. Arsenault, N. Owen-Smith // Oikos. - 2002. - Vol. 97 (3). - P. 313-318. - DOI 10.1034/j.1600-0706.2002.970301.x.

252. Janzen, D. H. Neotropical anachronisms: the fruits the gomphotheres ate / D. H. Janzen, P. S. Martin // Science. 1982. - Vol. 215 (4528). - P. 19-27. - DOI 10.1126/science.215.4528.19.

253. Bunney, K. The historical distribution of megaherbivores does not determine the distribution of megafaunal fruit in southern Africa / K. Bunney, M. Robertson, W. Bond // Biological Journal of the Linnean Society. - 2019. Vol. 128 (4). - P. 1039-1051. - DOI 10.1093/biolinnean/blz109.

254. Hawthorne, W. D. How important are forest elephants to the survival of woody plant species in Upper Guinean forests? / W. D. Hawthorne, M. P. E. Parren // Journal of Tropical Ecology. - 2000. - Vol. 16 (1). - P. 133-150. DOI 10.1017/S0266467400001310.

255. Campos-Arceiz, A. Megagardeners of the forest - the role of elephants in seed dispersal / A. Campos-Arceiz, S. Blake // Acta Oecologica. - 2011. - Vol. 37 (6). - P. 542-553. - DOI 10.1016/j.actao.2011.01.014. 
256. Changes in vegetation and earthworm populations under free grazing European Bison (Bison bonasus) in broadleaved forests of the Kaluzhskie Zaseki State Nature Reserve / N. V. Ivanova, V. E. Smirnov, L. G. Khanina, M. V. Bobrovsky, M. P. Shashkov // Biology Bulletin. - 2018. - Vol. 45. - P. 100-109. - DOI 10.1134/ S1062359018010053.

257. Smirnova, O. V. The concept "complementarity" as the basis for model and nature reconstruction of potential biota in the current climate / O. V. Smirnova, A. P. Gerasinka, A. A. Aleynikov // Russian Journal of Ecosystem Ecology. - 2018. - Vol. 3 (3). - DOI 10.21685/2500-0578-2018-3-1.

258. Scheffer, M. Synergy between small- and large-scale feedbacks of vegetation on the water cycle / M. Scheffer, M. Holmgren, V. Brovkin, M. Claussen // Global Change Biology. - 2005. - Vol. 11 (7). - P. 1003-1012. DOI 10.1111/j.1365-2486.2005.00962.x.

259. Climate tipping points - too risky to bet against / T. M. Lenton, J. Rockström, O. Gaffney, S. Rahmstorf, K. Richardson, W. Steffen, H. J. Schellnhuber // Nature. - 2019. - Vol. 575. - P. 592-595. - DOI 10.1038/d41586-01903595-0.

260. Does the terrestrial biosphere have planetary tipping points? / B. W. Brook, E. C. Ellis, M. P. Perring, A. W. Mackay, L. Blomqvist // Trends in Ecology \& Evolution. - 2013. - Vol. 28 (7). - P. 396-401. DOI 10.1016/j.tree.2013.01.016.

261. Humans, megafauna and environmental change in tropical Australia / M. I. Bird, L. B. Hutley, M. J. Lawes, J. Lloyd, J. G. Luly, P. V. Ridd, R. G. Roberts, S. Ulm, C. M. Wurster // Journal of Quaternary Science. - 2013. Vol. 28 (5). - P. 439-452. - DOI 10.1002/jqs.2639.

262. Miller, G. H. Disentangling the impacts of climate and human colonization on the flora and fauna of the Australian arid zone over the past $100 \mathrm{ka}$ using stable isotopes in avian eggshell / G. H. Miller, M. L. Fogel, J. W. Magee, M. K. Gagan // Quaternary Science Reviews. - 2016. - Vol. 151. - P. 27-57. - DOI 10.1016/ j.quascirev.2016.08.009.

263. Lovejoy, T. E. Amazon tipping point / T. E. Lovejoy, C. Nobre // Science Advances. - 2018. - Vol. 4 (2). P. eaat2340. - DOI 10.1126/sciadv.aat2340.

264. Increasing wildfires threaten historic carbon sink of boreal forest soils / X. J. Walker, J. L. Baltzer, S. G. Cumming, N. J. Day, C. Ebert, S. Goetz, J. F. Johnstone, S. Potter, B. M. Rogers, E. A. G. Schuur, M. R. Turetsky, M. C. Mack // Nature. - 2019. - Vol. 572 (7770). - P. 520-523. - DOI 10.1038/s41586-019-1474-y.

265. Acanakwo, E. F. Termites confer resistance to changes in tree composition following reduced browsing in an African savanna / E. F. Acanakwo, P. Okullo, D. Sheil, S. R. Moe // Journal of Vegetation Science. - 2018. Vol. 29 (6). - P. 989-998. - DOI 10.1111/jvs.12682.

\section{References}

1. Gorshkov V. G., Makarieva A. M. Russian Journal of Ecosystem Ecology. 2020, vol. 5 (1). DOI 10.21685/25000578-2020-1-1.

2. Sheil D. Forest Ecosystems. 2018, vol. 5 (19), pp. 1-22. DOI 10.1186/s40663-018-0138-y.

3. Paul G. Annals of Carnegie Museum. 2019, vol. 85 (4), pp. 335-358. DOI 10.2992/007.085.0403.

4. Burness G. P., Diamond J., Flannery T. Proceedings of the National Academy of Sciences of the United States of America. 2001, vol. 98 (25), pp. 14518-14523. DOI 10.1073/pnas.251548698.

5. Whitlock J. A. Palaeogeography, Palaeoclimatology, Palaeoecology. 2011, vol. 309 (3-4), pp. 333-341. DOI 10.1016/j.palaeo.2011.07.001.

6. Barrett P. M. Annual Review of Earth and Planetary Sciences. 2014, vol. 42, pp. 207-230. DOI 10.1146/annurev-earth-042711-105515.

7. Larramendi A. Acta Palaeontologica Polonica. 2016, vol. 61 (3), pp. 537-575. DOI 10.4202/app.00136.2014.

8. Fortelius M., Kappelman J. Zoological Journal of the Linnean Society. 2008, vol. 108 (1), pp. 85-101. DOI 10.1111/j.1096-3642.1993.tb02560.x.

9. Ripple W. J., Newsome T. M., Wolf C., Dirzo R., Everatt K. T., Galetti M., Hayward M. W., Kerley G. I. H., Levi T., Lindsey P. A., Macdonald D. W., Malhi Y., Painter L. E., Sandom C. J., Terborgh J., Van Valkenburgh B. Science Advances. 2015, vol. 1 (4), P. e1400103. DOI 10.1126/sciadv.1400103.

10. Hansen D. M., Galetti M. Science. 2009, vol. 324 (5923), pp. 42-43. DOI 10.1126/science.1172393.

11. Galetti M., Moleón M., Jordano P., Pires M. M., Guimarães P. R. Jr., Pape T., Nichols E., Hansen D., Olesen J. M., Munk M., de Mattos J. S., Schweiger A. H., Owen-Smith N., Johnson C. N., Marquis R. J., Swenning J.-C. Biological Reviews. 2018, vol. 93 (2), pp. 845-862. DOI 10.1111/brv.12374.

12. Gill J. L. New Phytologist. 2014, vol. 201 (4), pp. 1163-1169. DOI 10.1111/nph.12576.

13. Puspaningrum M. R., van den Bergh G. D., Chivas A. R., Setiabudi E., Kurniawan I. Quaternary Science Reviews. 2020, vol. 228, pp. 106007. DOI 10.1016/j.quascirev.2019.106007.

14. Pérez-Crespo V. A., Prado J. L., Alberdi M. T., Arroyo-Cabrales J., Johnson E. Ameghiniana [ ]. 2016, vol. 53 (1), pp. 39-51. DOI 10.5710/AMGH.02.06.2015.2842.

15. Saarinen J., Karme A. Palaeogeography, Palaeoclimatology, Palaeoecology. 2017, vol. 476, pp. $42-54$. DOI 10.1016/j.palaeo.2017.03.027.

16. Lister A., Sher A. Science. 2015, vol. 350 (6262), pp. 805-809. DOI 10.1126/science.aac5660. 
17. Asevedo L., Winck G. R., Mothé D., Avilla L. S. Quaternary International. 2012, vol. 255, P. $42-52$. DOI 10.1016/j.quaint.2011.08.037.

18. Stuart A. Quaternary International. 2005, vol. 126-128, pp. 171-177. DOI 10.1016/j.quaint.2004.04.021.

19. Palkopoulou E., Lipson M., Mallick S., Nielsen S., Rohland N., Baleka S., Karpinski E., Ivancevic A. M., To T.-H., Kortschak R. D., Raison J. M., Qu Z., Chin T.-J., Alt K. W., Claesson S., Dalén L., MacPhee R. D. E., Meller H., Roca A. L., Ryder O. A., Heiman D., Young S., Breen M., Williams C., Aken B. L., Ruffier M., Karlsson E., Johnson J., Di Palma F., Alfoldi J., Adelson D. L., Mailund T., Munch K., Lindblad-Toh K., Hofreiter M., Poinar H., Reich D. Proceedings of the National Academy of Sciences of the United States of America. 2018, vol. 115 (11), pp. E2566-E2574. DOI 10.1073/pnas.1720554115.

20. Palombo M. R., Filippi M. L., Iacumin P., Longinelli A., Barbieri M., Maras A. Quaternary International. 2005, vol. 126-128, pp. 153-170. DOI 10.1016/j.quaint.2004.04.020.

21. Orlova L. A., Vasil'ev S. K., Kuzmin Ya. V., Kosintsev P. A. Doklady Biological Sciences. 2008, vol. 423 (1), pp. 403-405. DOI 10.1134/S0012496608060100.

22. Tiunov A. V., Kirillova I. V. Rapid Communications in Mass Spectrometry. 2010, vol. 24 (21), pp. 3146-3150. DOI $10.1002 / \mathrm{rcm} .4755$

23. Figueirido B., Palmqvist P., Pérez-Claros J. A. Journal of Zoology. 2009, vol. 277 (1), pp. $70-80$. DOI 10.1111/j.1469-7998.2008.00511.x.

24. Richards M. P., Pacher M., Stiller M., Quilés J., Hofreiter M., Constantin S., Zilhão J., Trinkaus E. Proceedings of the National Academy of Sciences of the United States of America. 2008, vol. 105 (2), pp. 600-604. DOI 10.1073/pnas.0711063105.

25. Bargo M. S. Acta Palaeontologica Polonica. 2001, vol. 46 (2), pp. 173-192.

26. Green J. L., Kalthoff D. Journal of Mammalogy. 2015, vol. $96 \quad$ (4), pp. $645-657$. DOI 10.1093/jmammal/gyv045.

27. Wroe S., Crowther M., Dortch J., Chong J. Proceedings of the Royal Society B: Biological Sciences. 2004, vol. 271, pp. S34-S36. DOI 10.1098/rsbl.2003.0095.

28. Price G. J., Ferguson K. J., Webb G. E., Feng Y., Higgins P., Nguyen A. D., Zhao J., Joannes-Boyau R., Louys J. Proceedings of the Royal Society B: Biological Sciences. 2017, vol. 284 (1863), p. 20170785. DOI 10.1098/rspb.2017.0785.

29. Smith F. A., Smith R. E. E., Lyons S. K., Payne J. L. Science. 2018, vol. 360 (6386), pp. $310-313$. DOI 10.1126/science.aao5987.

30. Hempson G. P., Archibald S., Bond W. J. Scientific Reports. 2017, vol. 7 (1), pp. 17196. DOI 10.1038/s41598017-17348-4.

31. Grubb P., Groves C. P., Dudley J. P., Shoshani J. Elephant. 2000, vol. 2 (4), pp. 1-4. DOI 10.22237/elephant/1521732169.

32. Roca A. L., Georgiadis N., Pecon-Slattery J., O'Brien S. J. Science. 2001, vol. 293 (5534), pp. 1473-1477. DOI 10.1126/science.1059936.

33. Ishida Y., Oleksyk T. K., Georgiadis N. J., David V. A., Zhao K., Stephens R. M., Kolokotronis S.-O., Roca A. L. PLOS One. 2011, vol. 6 (6), pp. e20642. DOI 10.1371/journal.pone.0020642.

34. Roca A. L., Georgiadis N., O'Brien S. J. Quaternary International. 2007, vol. 169, pp. 4-16. DOI 10.1016/j.quaint.2006.08.008.

35. Rohland N., Reich D., Mallick S., Meyer M., Green R. E., Georgiadis N. J., Roca A. L., Hofreiter M. PLOS Biology. 2010, vol. 8 (12), p. e1000564. DOI 10.1371/journal.pbio.1000564.

36. Chase M. J., Schlossberg S., Griffin C. R., Bouché P. J., Djene S. W., Elkan P. W., Ferreira S., Grossman F., Kohi E. M., Landen K. PeerJ. 2016, vol. 4, p. e2354. DOI 10.7717/peerj.2354.

37. Maisels F., Strindberg S., Blake S., Wittemyer G., Hart J., Williamson E. A., Aba'a R. A., Abitsi G., Ambahe R. D., Amsini F. et al. PLOS One. 2013, vol. 8 (3), p. e59469. DOI 10.1371/journal.pone.0059469.

38. Groves C. P., Grubb P. Elephant. 2000, vol. 2 (4), p. 4. DOI 10.22237/elephant/1521732173.

39. Belovsky G. E. Evolutionary Ecology. 1997, vol. 11 (6), pp. 641-672. DOI 10.1023/ A:1018430201230.

40. Ritchie M. E., Olff H. Nature. 1999, vol. 400 (6744), pp. 557-560. DOI 10.1038/23010.

41. Laws R. M. Oikos. 1970, vol. 21 (1), pp. 1-15. DOI 10.2307/3543832.

42. Laws R. M., Parker I. S. C., Johnstone R. C. B. Elephants and their habitats: The ecology of elephants in North Bunyoro, Uganda. Oxford, England: Clarendon Press, 1975.

43. Kortlandt A. Tropical rain-forest: the Leeds symposium. Leeds: Leeds Philosophical and Literary Society, 1984, pp. 205-226.

44. Owen-Smith N., Chafota J. Journal of Mammalogy. 2012, vol. 93 (3), pp. 698-705. DOI 10.1644/11-MAMM-A350.1 .

45. Barnes R. F. W. African Journal of Ecology. 1982, vol. 20 (2), pp. 123-136. DOI 10.1111/j.13652028.1982.tb00282.x.

46. Owen-Smith N., Page B., Teren G., Druce D. J. Savanna Woody Plants and Large Herbivores. Wiley Online, 2019, pp. 585-611. DOI 10.1002/9781119081111.ch17.

47. Clauss M., Frey R., Kiefer B., Lechner-Doll M., Loehlein W., Polster C., G. Rössner, W. J. Streich Oecologia. 2003, vol. 136 (1), pp. 14-27. DOI 10.1007/s00442-003-1254-z. 
48. Clauss M., Hummel J. Mammal Review. 2005, vol. 35 (2), pp. 174-187. DOI 10.1111/j.1365-2907.2005. 00062.x.

49. Ullrey D. E., Crissey S. D., Hintz H. F. East Lansing. MI, USA: Nutrition Advisory Group Handbook, Factsheet 004, 1997, 19 p.

50. Kuhnigk T., Borst E.-M., Ritter A., Kämpfer P., Graf A., Hertel H., König H. Systematic and Applied Microbiology. 1994, vol. 17 (1), pp. 76-85. DOI 10.1016/S0723-2020(11)80034-2.

51. Tsegaye B., Balomajumder C., Roy P. International Microbiology. 2019, vol. 22 (1), pp. $29-39$. DOI 10.1007/s10123-018-0024-z.

52. Asner G. P., Levick S. R. Ecology Letters. 2012, vol. 15 (11), pp. 1211-1217. DOI 10.1111/j.14610248.2012.01842.x.

53. Asner G. P., Vaughn N., Smit I. P., Levick S. Ecography. 2016, vol. 39 (2), pp. $240-252$. DOI 10.1111/ecog.01640.

54. Pellegrini A. F., Pringle R. M., Govender N., Hedin L. O. Journal of Ecology. 2017, vol. 105 (1), pp. $111-121$. DOI 10.1111/1365-2745.12668.

55. Mosugelo D. K., Moe S. R., Ringrose S., Nellemann C. African Journal of Ecology. 2002, vol. 40 (3), pp. 232240. DOI 10.1046/j.1365-2028.2002.00361.x.

56. Kalwij J. M., de Boer W. F., Mucina L., Prins H. H. T., Skarpe C., Winterbach C. Ecological Applications. 2010, vol. 20 (1), pp. 222-233. DOI 10.1890/09-0541.1.

57. Morrison T. A., Holdo R. M., Anderson T. M. Journal of Ecology. 2016, vol. 104 (2), pp. $409-418$. DOI 10.1111/1365-2745.12517.

58. Midgley J. J., Balfour D., Kerley G. I. South African Journal of Science. 2005, vol. 101 (5-6), pp. $213-215$.

59. Kissa D. O., Sheil D. Forest Ecology and Management. 2012, vol. 263, pp. $114-121$. DOI 10.1016/j.foreco.2011.09.020.

60. Ssali F., Sheil D., Nkurunungi J. B. African Journal of Ecology. 2013, vol. 51 (1), pp. 55-65. DOI 10.1111/aje.12006.

61. Struhsaker T. T., Lwanga J. S., Kasenene J. M. Journal of Tropical Ecology. 1996, vol. 12 (1), pp. $45-64$. DOI 10.1017/S0266467400009305.

62. Omeja P. A., Jacob A. L., Lawes M. J., Lwanga J. S., Rothman J. M., Tumwesigye C., Chapman C. A. Biotropica. 2014, vol. 46 (6), pp. 704-711. DOI 10.1111/btp.12154.

63. Sheil D., Salim A. Biotropica. 2004, vol. 36 (4), pp. 505-521. DOI 10.1646/1599.

64. Buechner H. K., Dawkins H. C. Ecology. 1961, vol. 42 (4), pp. 752-766. DOI 10.2307/1933504.

65. Odoi J. B. Resilience of forest trees to debarking by elephants in Rabongo Forest, Murchison Falls National Park. Uganda: MSc Thesis. Makerere: Kampala, 2014.

66. Gill R. Forestry. 1992, vol. 65 (4), pp. 363-388. DOI 10.1093/forestry/65.4.363-a.

67. Krojerová-Prokešová J., Homolka M., Heroldová M., Barančeková M., Baňař P., Kamler J., Modlinger R., Purchart L., Zejda J., Suchomel J. Forest Ecology and Management. 2018, vol. 408, pp. $137-147$. DOI 10.1016/j.foreco.2017.10.047.

68. McDowell N., Allen C. D., Anderson-Teixeira K., Brando P., Brienen R., Chambers J., Christoffersen B., Davies S., Doughty C., Duque A., Espirito-Santo F., Fisher R., Fontes C. G., Galbraith D., Goodsman D., Grossiord C., Hartmann H., Holm J., Johnson D. J., Kassim A. R., Keller M., Koven C., Kueppers L., Kumagai T., Malhi Y., McMahon S. M., Mencuccini M., Meir P., Moorcroft P., Muller-Landau H. C., Phillips O. L., Powell T., Sierra C. A., Sperry J., Warren J., Xu C., Xu X. New Phytologist. 2018, vol. 219 (3), pp. 851-869. DOI 10.1111/nph.15027.

69. Hamilton A. C. A Field Guide to Uganda Forest Trees. Kampala, Uganda: Makerere University, 1981,280 p.

70. Höft R., Höft M. Biological Conservation. 1995, vol. 73 (1), pp. 67-79. DOI 10.1016/0006-3207(95)90067-5.

71. Sheil D., Ducey M. Journal of Tropical Ecology. 2002, vol. 18 (5), pp. 671-686. DOI 10.1017/ S0266467402002444

72. Sheil D. Forest Biodiversity Research, Monitoring and Modeling: Conceptual background and Old World case studies. Paris: M.A.B. UNESCO, 1998, pp. 399-428.

73. Lewis S. L., Lopez-Gonzalez G., Sonké B., Affum-Baffoe K., Baker T. R., Ojo L. O., Phillips O. L., Reitsma J. M., White L., Comiskey J. A., Djuikouo M. N., Ewango C. E. N., Feldpausch T. R., Hamilton A. C., Gloor M., Hart T., Hladik A., Lloyd J., Lovett J. C., Makana J. R., Malhi Y., Mbago F. M., Ndangalasi H. J., Peacock J., Peh K. S. H., Sheil D., Sunderland T., Swaine M. D., Taplin J., Taylor D., Thomas S. C., Votere R., Wöll H. Nature. 2009, vol. 457 (7232), pp. 1003-1006. DOI 10.1038/nature07771.

74. Hubau W., Lewis S. L., Phillips O. L., Affum-Baffoe K., Beeckman H., Cuní-Sanchez A., Daniels A. K., Ewango C. E. N., Fauset S., Mukinzi J. M., Sheil D., Sonké B., Sullivan M. J. P., Sunderland T. C. H., Taedoumg H., Thomas S. C., White L. J. T., Abernethy K. A., Adu-Bredu S., Amani C. A., Baker T. R., Banin L. F., Baya F., Begne S. K., Bennett A. C., Benedet F., Bitariho R., Bocko Y. E., Boeckx P., Boundja P., Brienen R. J. W., Brncic T., Chezeaux E., Chuyong G. B., Clark C. J., Collins M., Comiskey J. A., Coomes D. A., Dargie G. C., Haulleville T., Kamdem M. N. D., Doucet J.-L., Esquivel-Muelbert A., Feldpausch T. R., Fofanah A., Foli E. G., Gilpin M., Gloor E., Gonmadje C., Gourlet-Fleury S., Hall J. S., Hamilton A. C., Harris D. J., Hart T. B., Hockemba M. B. N., Hladik A., Ifo S. A., Jeffery K. J., Jucker T., Yakusu E. K., Kearsley E., Kenfack D., Koch A., Leal M. E., Levesley A., Lindsell J. A., Lisingo J., Lopez-Gonzalez G., Lovett J. C., Makana J.-R., Malhi Y., Marshall A. R., Martin J., Martin E. H., Mbayu F. M., Medjibe V. P., Mihindou V., Mitchard E. T. A., Moore S., Munishi P. K. T., 
Bengone N. N., Ojo L., Ondo F. E., Peh K. S. H., Pickavance G. C., Poulsen A. D., Poulsen J. R., Qie L., Reitsma J., Rovero F., Swaine M. D., Talbot J., Taplin J., Taylor D. M., Thomas D. W., Toirambe B., Mukendi J. T., Tuagben D., Umunay P. M.,. van der Heijden G. M. F et al. Nature. 2020, vol. 579 (7797), pp. 80-87. DOI 10.1038/s41586-020-2035-0.

75. White L. J., Tutin C. E., Fernandez M. African Journal of Ecology. 1993, vol. 31 (3), pp. $181-199$. DOI 10.1111/j.1365-2028.1993.tb00532.x.

76. Cardoso A. W., Malhi Y., Oliveras I., Lehmann D., Ndong J. E., Dimoto E., Bush E., Jeffery K., Labriere N., Lewis S. L., White L. T. J., Bond W., Abernethy K. Ecosystems. 2020, vol. 23, pp. $602-616$. DOI 10.1007/s10021-019-00424-3.

77. Terborgh J., Davenport L. C., Niangadouma R., Dimoto E., Mouandza J. C., Scholtz O., Jaen M. R. Ecography. 2016, vol. 39 (2), pp. 180-186. DOI 10.1111/ecog.01641.

78. Klaus G., Klaus-Hügi C., Schmid B. Journal of Tropical Ecology. 1998, vol. 14 (6). pp. 829-839. DOI $10.1017 / \mathrm{S} 0266467498000595$.

79. Turkalo A. K., Wrege P. H., Wittemyer G. PLOS One. 2013, vol. 8 (12), p. e85154. DOI 10.1371/ journal.pone.0085154.

80. Berzaghi F., Longo M., Ciais P., Blake S., Bretagnolle F., Vieira S., Scaranello M., Scarascia-Mugnozza G., Doughty C. E. Nature Geoscience. 2019, vol. 12 (9), pp. 725-729. DOI 10.1038/s41561-019-0395-6.

81. Phillips O. L., Sullivan M. J. P., Baker T. R., Mendoza A. M., Vargas P. N., Vásquez R. Surveys in Geophysics. 2019, vol. 40, pp. 913-935. DOI 10.1007/s10712-019-09540-0.

82. Connell J. H. Population Dynamics. UK: British Ecological Society, 1979, pp. 141-163.

83. Fineblum W. L., Rausher M. D. Nature. 1995, vol. 377 (6549), pp. 517-520. DOI 10.1038/377517a0.

84. Cipollini D., Walters D., Voelckel C. Annual Plant Reviews. 2014, vol. 47, pp. $263-307$. DOI 10.1002/9781119312994.apr0512.

85. Darwin C. On the Origin of Species by Means of Natural Selection. London, UK: John Murray, 1859.

86. Podani J., Kun Á., Szilágyi A. Journal of the History of Biology. 2018, vol. 51 (2), pp. $259-281$. DOI 10.1007/s10739-017-9488-5.

87. Lee P. C., Fishlock V., Webber C. E., Moss C. J. Behavioral Ecology and Sociobiology. 2016, vol. 70 (3), pp. 337-345. DOI 10.1007/s00265-015-2051-5.

88. Foley C. A. H., Faust L. J. Oryx. 2010, vol. 44 (2), pp. 205-212. DOI 10.1017/S0030605309990706.

89. Calef G. W. African Journal of Ecology. 1988, vol. 26 (4), pp. 323-327. DOI 10.1111/j.13652028.1988.tb00984.x

90. Turkalo A. K., Wrege P. H., Wittemyer G. PLOS One. 2018, vol. 13 (2), p. e0192777. DOI 10.1371/journal.pone.0192777.

91. Gough K. F., Kerley G. I. H. Oryx. 2006, vol. 40 (4), pp. 434-441. DOI 10.1017/S0030605306001189.

92. de Knegt H. J., van Langevelde F., Skidmore A. K., Delsink A., Slotow R., Henley S., Bucini G., de Boer W. F., Coughenour M. B., Grant C. C., Heitkönig I. M. A., Henley M., Knox N. M., Kohi E. M., Mwakiwa E., Page B. R., Peel M., Pretorius Y., van Wieren S. E., Prins H. H. T. Journal of Animal Ecology. 2011, vol. 80 (1), pp. $270-281$. DOI 10.1111/j.1365-2656.2010.01764.x.

93. Western D. African Journal of Ecology. 1975, vol. 13 (3-4), pp. 265-286. DOI 10.1111/j.13652028.1975.tb00139.x.

94. Dunkin R. C., Wilson D., Way N., Johnson K., Williams T. M. Journal of Experimental Biology. 2013, vol. 216 (15), pp. 2939-2952. DOI 10.1242/jeb.080218.

95. Buss I. O. The Journal of Wildlife Management. 1961, vol. 25 (2), pp. 131-148. DOI 10.2307/3798671.

96. Chamaillé-Jammes S., Mtare G., Makuwe E., Fritz H. PLOS One. 2013, vol. 8 (3), p. e59164. DOI 10.1371/journal.pone.0059164.

97. Ndlovu M., Pérez-Rodríguez A., Devereux E., Thomas M., Colina A., Molaba L. Biology Letters. 2018, vol. 14 (8), pp. 20180360. DOI 10.1098/rsbl.2018.0360.

98. Stommel C., Hofer H., Grobbel M., East M. L. Mammalian Biology. 2016, vol. 81 (1), pp. $21-30$. DOI 10.1016/j.mambio.2015.08.005.

99. Ramey E. M., Ramey R. R., Brown L. M., Kelley S. T. Pachyderm. 2013, vol. 53, pp. 66-72.

100. Ssali F., Moe S. R., Sheil D. Biotropica. 2019, vol. 2019 (5), pp. 652-663. DOI 10.1111/btp.12703.

101. Obanda V., Iwaki T., Mutinda N. M., Gakuya F. African Journal of Wildlife Research. 2011, vol. 41 (2), pp. 167-173. DOI 10.3957/056.041.0203.

102. Kinsella J. M., Deem S. L., Blake S., Freeman A. S. Comparative Parasitology. 2004, vol. 71 (2), pp. $104-111$. DOI 10.1654/4131.

103. Baines L., Morgan E. R., Ofthile M., Evans K. International Journal for Parasitology. 2015, vol. 4 (1), pp. $43-48$. DOI 10.1016/j.ijppaw.2015.01.004.

104. Vítovec J., Kotrlá B., Haji H., Hayles L. B. Zentralblatt für Veterinärmedizin Reihe B [ ]. 1984, vol. 31 (1-10), pp. 597-602. DOI 10.1111/j.1439-0450.1984.tb01340.x

105. Grobler D. G., Raath J. P., Braack L. E., Keet D. F., Gerdes G. H., Barnard B. J., Kriek N. P., Jardine J., Swanepoel R., Braack L. Onderstepoort Journal of Veterinary Research. 1995, vol. 62, pp. 97-108.

106. Van Sandwyk J. H. d. T., Bennett N. C., Swanepoel R., Bastos A. D. S. Veterinary Microbiology. 2013, vol. 162 (1), pp. 23-31. DOI 10.1016/j.vetmic.2012.08.008. 
107. Obanda V., Poghon J., Yongo M., Mulei I., Ngotho M., Waititu K., Makumi J., Gakuya F., Omondi P., Soriguer R. C., Alasaad S. Epidemiology. 2013, vol. 141 (7), pp. 1476-1480. DOI 10.1017/S0950268813000022.

108. Miller M. A., Buss P., Roos E. O., Hausler G., Dippenaar A., Mitchell E., van Schalkwyk L., Robbe-Austerman S., Waters W. R., Sikar-Gang A., Lyashchenko K. P., C. Parsons S. D., Warren R., van Helden P. Frontiers in Veterinary Science. 2019, vol. 6, p. 18. DOI 10.3389/fvets.2019.00018.

109. Rothschild B. M., Laub R. Naturwissenschaften [ ]. 2006, vol. 93 (11), pp. 557-564. DOI 10.1007/s00114-0060144-8.

110. Leshchinskiy S. V. Quaternary International. 2012, vol. 276, pp. 155-169. DOI 10.1016/j.quaint.2012.05.025

111. Power R. J., Compion R. X. S. Journal of African Zoology. 2009, vol. 44 (1), pp. 36-44. DOI 10.3377/004.044.0104.

112. Salnicki J., Teichmann M., Wilson V. J., Murindagomo F. Koedoe [ ]. 2001, vol. 44 (2), pp. $79-83$.

113. Loveridge A. J., Hunt J. E., Murindagomo F., Macdonald D. W. Journal of Zoology. 2006, vol. 270 (3), pp. 523-530. DOI 10.1111/j.1469-7998.2006.00181.x.

114. Wato Y. A., Heitkönig I. M. A., van Wieren S. E., Wahungu G., Prins H. H. T., van Langevelde F. Biological Conservation. 2016, vol. 203, pp. 89-96. DOI 10.1016/j.biocon.2016.09.007.

115. van Valkenburgh B., Hayward M. W., Ripple W. J., Meloro C., Roth V. L. Proceedings of the National Academy of Sciences of the United States of America. 2016, vol. 113 (4), pp. 862-867. DOI 10.1073/pnas.1502554112.

116. Edwards E. J., Osborne C. P., Strömberg C. A. E., Smith S. A., C 4 Grasses Consortium Science. 2010, vol. 328 (5978), pp. 587-591. DOI 10.1126/science.1177216.

117. Sage R. New Phytologist. 2004, vol. 161 (2), pp. 341-370. DOI 10.1111/j.1469-8137.2004.00974.x.

118. Quirk J., Bellasio C., Johnson D. A., Osborne C. P., Beerling D. J. Functional Ecology. 2019, vol. 33 (3), pp. 388-398. DOI 10.1111/1365-2435.13240.

119. Christin P.-A., Osborne C. P. New Phytologist. 2014, vol. 204 (4), pp. 765-781. DOI 10.1111/nph.13033.

120. Ladd B., Peri P. L., Pepper D. A., Silva L. C. R., Sheil D., Bonser S. P., Laffan S. W., Amelung W., Ekblad A., Eliasson P., Bahamonde H., Duarte-Guardia S., Bird M. Journal of Ecology. 2014, vol. 102 (6), pp. 1606-1611. DOI 10.1111/1365-2745.12309.

121. Cerling T. E., Wynn J. G., Andanje S. A., Bird M. I., Korir D. K., Levin N. E., Mace W., Macharia A. N., Quade J., Remien C. H. Nature. 2011, vol. 476, pp. 51-56. DOI 10.1038/nature10306.

122. Bird M. I., Haig J., Hadeen X., Rivera-Araya M., Wurster C. M., Zwart C. Palaeogeography, Palaeoclimatology, Palaeoecology. 2020, vol. 538, p. 109445. DOI 10.1016/j.palaeo.2019.109445.

123. Tipple B. J., Pagani M. Annual Review of Earth and Planetary Sciences. 2007, vol. 35, pp. 435-461. DOI 10.1146/annurev.earth.35.031306.140150.

124. Karp A. T., Behrensmeyer A. K., Freeman K. H. Proceedings of the National Academy of Sciences of the United States of America. 2018, vol. 115 (48), pp. 12130-12135. DOI 10.1073/pnas.1809758115.

125. Polissar P. J., Rose C., Uno K. T., Phelps S. R., deMenocal P. Nature Geoscience. 2019, vol. 12 (8), pp. 657-660. DOI 10.1038/s41561-019-0399-2.

126. Retallack G. J. Journal of Geology. 2001, vol. 109 (4), pp. 407-426. DOI 10.1086/320791.

127. Andrae J. W., McInerney F. A., Polissar P. J., Sniderman J. M. K., Howard S., Hall P. A., Phelps S. R. Geophysical Research Letters. 2018, vol. 45 (10), pp. 4831-4840. DOI 10.1029/2018GL077833.

128. Vorontsova M. S., Besnard G., Forest F., Malakasi P., Moat J., Clayton W. D., Ficinski P., Savva G. M., Nanjarisoa O. P., Razanatsoa J., Randriatsara F. O., Kimeu J. M., Luke W. R. Q., Kayombo C., Linder H. P. Proceedings of the Royal Society B: Biological Sciences. 2016, vol. 283 (1823), p. 20152262. DOI 10.1098/rspb.2015.2262.

129. Crowley B. E., Godfrey L. R., Irwin M. T. American Journal of Primatology. 2011, vol. 73 (1), pp. $25-37$. DOI 10.1002/ajp.20817.

130. Pedrono M., Griffiths O. L., Clausen A., Smith L. L., Griffiths C. J., Wilmé L., Burney D. A. Biological Conservation. 2013, vol. 159, pp. 501-506. DOI 10.1016/j.biocon.2012.11.027.

131. Large R. R., Mukherjee I., Gregory D., Steadman J., Corkrey R., Danyushevsky L. V. J. M. D. Mineralium Deposita. 2019, vol. 54 (4), pp. 485-506. DOI 10.1007/s00126-019-00873-9.

132. Scott A. C., Glasspool I. J. Proceedings of the National Academy of Sciences of the United States of America. 2006, vol. 103 (29), pp. 10861-10865. DOI 10.1073/pnas.0604090103.

133. Glasspool I. J., Edwards D., Axe L. Geology. 2004, vol. 32 (5), pp. 381-383. DOI 10.1130/G20363.1.

134. Liu Z., Selby D., Hackley P. C., Over D. J. GSA Bulletin. 2020, vol. 132 (9-10), pp. $2043-2054$. DOI 10.1130/B35457.1.

135. Meyer-Berthaud B., Scheckler S. E., Wendt J. Nature. 1999, vol. 398 (6729), pp. $700-701$. DOI 10.1038/19516.

136. Cressler W. L. Palaios. 2001, vol. 16 (2), pp. 171-174. DOI 10.2307/3515528.

137. Ward P., Labandeira C., Laurin M., Berner R. A. Proceedings of the National Academy of Sciences of the United States of America. 2006, vol. 103 (45), pp. 16818-16822. DOI 10.1073/pnas.0607824103.

138. Berner R. A., Beerling D. J., Dudley R., Robinson J. M., Wildman R. A. Jr. Annual Review of Earth and Planetary Sciences. 2003, vol. 31 (1), pp. 105-134. DOI 10.1146/annurev.earth.31.100901.141329.

139. Nelson M. I. Combustion Theory and Modelling. 2001, vol. 5 (1), pp. 59-83. DOI 10.1088/1364-7830/5/1/304. 
140. Falcon-Lang H. J. Palaeogeography Palaeoclimatology Palaeoecology. 2000, vol. 164 (1-4), pp. 339-355. DOI 10.1016/S0031-0182(00)00193-0.

141. Falcon-Lang H. J., Bashforth A. R. Geology. 2004, vol. 32 (5), pp. 417-420. DOI 10.1130/G20371.1.

142. He T., Belcher C. M., Lamont B. B., Lim S. L. Journal of Ecology. 2016, vol. 104 (2), pp. $352-363$. DOI 10.1111/1365-2745.12513.

143. Hernandez-Castillo G. R., Stockey R. A., Rothwell G. W., Mapes G. Review of Palaeobotany. 2009, vol. 157 (3-4), pp. 218-237. DOI 10.1016/j.revpalbo.2009.05.003.

144. Bourguignon T., Lo N., Cameron S. L., Šobotník J., Hayashi Y., Shigenobu S., Watanabe D., Roisin Y., Miura T., Evans T. A. Molecular Biology and Evolution. 2014, vol. 32 (2), pp. $406-421$. DOI 10.1093/molbev/msu308.

145. He T., Lamont B. B. National Science Review. 2017, vol. 5 (2), pp. 237-254. DOI 10.1093/nsr/nwx041.

146. Sahney S., Benton M. J., Falcon-Lang H. J. Geology. 2010, vol. 38 (12), pp. 1079-1082. DOI 10.1130/G31182.1.

147. Lamont B. B., He T., Yan Z. Biological Reviews. 2019, vol. 94 (3), pp. 903-928. DOI 10.1111/brv.12483.

148. Bowman D. M. J. S., French B. J., Prior L. D. Frontiers in Plant Science. 2014, vol. 5, p. 590. DOI 10.3389/fpls.2014.00590.

149. Pausas J. G., Keeley J. E., Schwilk D. W. Journal of Ecology. 2017, vol. 105 (2), pp. $289-297$. DOI 10.1111/1365-2745.12691.

150. Zavada M. S., Mentis M. T. American Midland Naturalist. 1992, vol. 127 (1), pp. 1-12. DOI 10.2307/2426316.

151. Williams V. S., Barrett P. M., Purnell M. A. Proceedings of the National Academy of Sciences of the United States of America. 2009, vol. 106 (27), pp. 11194-11199. DOI 10.1073/pnas.0812631106.

152. Mallon J. C., Anderson J. S. PLOS ONE. 2014, vol. 9 (6), p. e98605. DOI 10.1371/journal.pone.0098605.

153. Bajdek P., Owocki K., Niedźwiedzki G. Palaeogeography, Palaeoclimatology, Palaeoecology. 2014, vol. 411, pp. 1-17. DOI 10.1016/j.palaeo.2014.06.013.

154. Chin K. Palaios. 2007, vol. 22 (5), pp. 554-566. DOI 10.2307/27670451.

155. Baghai-Riding N. L., DiBenedetto J. N. Gulf Coast Association of Geological Societies Transactions. 2001, vol. 51, pp. 9-20. DOI 10.1306/8626CE33-173B-11D7-8645000102C1865D.

156. Tiffney B. H. The Paleobotanist. 1992, vol. 41, pp. 87-97.

157. Saarinen J. The Ecology of Browsing and Grazing II. Cham, Switzerland: Springer, 2019, pp. 5-59.

158. Charles-Dominique T., Davies T. J., Hempson G. P., Bezeng B. S., Daru B. H., Kabongo R. M., Maurin O., Muasya A. M., van der Bank M., Bond W. J. Proceedings of the National Academy of Sciences of the United States of America. 2016, vol. 113 (38), pp. E5572-E5579. DOI 10.1073/pnas.1607493113.

159. Coe M., Dilcher D., Farlow J., Jarzen O., Russell D. The origin of angiosperms and their biological consequences. Cambridge, UK: Cambridge University Press, 1987, pp. 225-258.

160. Royo A. A., Carson W. P. Canadian Journal of Forest Research-Revue Canadienne De Recherche Forestiere. 2006, vol. 36 (6), pp. 1345-1362. DOI 10.1139/x06-025.

161. George L. O., Bazzaz F. A. Ecology. 1999, vol. 80 (3), pp. 833-845. DOI 10.1890/00129658(1999)080[0833:TFUAAE]2.0.CO;2.

162. Marrs R. H., Watt A. S. Journal of Ecology. 2006, vol. 94 (6), pp. 1272-1321. DOI 10.1111/j.13652745.2006.01177.x.

163. Ssali F., Moe S. R., Sheil D. Forest Ecology and Management. 2017, vol. 402, pp. $166-176$. DOI 10.1016/j.foreco.2017.07.050.

164. Ssali F., Moe S. R., Sheil D. Ecology and Evolution. 2018, vol. 8 (8), pp. 4224-4236. DOI 10.1002/ece3.3944.

165. Ssali F., Moe S. R., Sheil D. Plant Ecology. 2019, vol. 220 (1), pp. 41-55. DOI 10.1007/s11258-018-0901-8.

166. Masozera A. Unpublished Report. Bronx Zoo, New York, USA: Wildlife Conservation Society, 2004.

167. Herbert T. D., Lawrence K. T., Tzanova A., Peterson L. C., Caballero-Gill R., Kelly C. S. Nature Geoscience. 2016, vol. 9 (11), pp. 843-847. DOI 10.1038/ngeo2813.

168. Bobe R. Journal of Arid Environments. 2006, vol. 66 (3), pp. 564-584. DOI 10.1016/j.jaridenv.2006.01.010.

169. Linder H. P., Lehmann C. E. R., Archibald S., Osborne C. P., Richardson D. M. Biological Reviews. 2018, vol. 93 (2), pp. 1125-1144. DOI 10.1111/brv.12388.

170. Beerling D. J., Osborne C. P. Global Change Biology. 2006, vol. 12 (11), pp. 2023-2031. DOI 10.1111/j.13652486.2006.01239.x.

171. Boers N., Marwan N., Barbosa H. M. J., Kurths J. Scientific Reports. 2017, vol. 7, pp. 41489. DOI 10.1038/srep41489.

172. Makarieva A. M., Gorshkov V. G. Hydrology and Earth System Sciences. 2007, vol. 11 (2), pp. $1013-1033$. DOI 10.5194/hess-11-1013-2007.

173. Lawrence D., Vandecar K. Nature Climate Change. 2015, vol. 5 (1), pp. 27-36. DOI 10.1038/nclimate2430.

174. Schmidt M. W., Torn M. S., Abiven S., Dittmar T., Guggenberger G., Janssens I. A., Kleber M., Kögel-Knabner I., Lehmann J., Manning D. A. C., Nannipieri P., Rasse D. P., Weiner S., Trumbore S. E. Nature. 2011, vol. 478 (7367), p. 49. DOI 10.1038/nature10386.

175. Maslin M. Nature. 2016, vol. 540 (7632), pp. 208-209. DOI 10.1038/540208a.

176. Hoag C., Svenning J.-C. Annual Review of Environment and Resources. 2017, vol. 42, pp. $27-54$. DOI 10.1146/annurev-environ-102016-060653. 
177. Maley J. Proceedings of the Royal Society of Edinburgh, Section B: Biological Sciences. 1996, vol. 104, pp. 31-73. DOI 10.1017/S0269727000006114.

178. Dupont L. M., Caley T., Castañeda I. S. Climate of the Past. 2019, vol. 15 (3), pp. $1083-1097$. DOI 10.5194/cp-15-1083-2019.

179. Leite Y. L. R., Costa L. P., Loss A. C., Rocha R. G., Batalha-Filho H., Bastos A. C., Quaresma V. S., Fagundes V., Paresque R., Passamani M., Pardini R. Proceedings of the National Academy of Sciences of the United States of America. 2016, vol. 113 (4), pp. 1008-1013. DOI 10.1073/pnas.1513062113.

180. Jones M. W., Santín C., van der Werf G. R., Doerr S. H. Nature Geoscience. 2019, vol. 12 (9), pp. 742-747. DOI 10.1038/ s41561-019-0403-x.

181. Berner R. A., VandenBrooks J. M., Ward P. D. Science. 2007, vol. 316 (5824), pp. 557-558. DOI 10.1126/science.1140273.

182. Sherwood S. C., Roca R., Weckwerth T. M., Andronova N. G. Reviews of Geophysics. 2010, vol. 48 (2). DOI 10.1029/2009rg000301.

183. Makarieva A. M., Gorshkov V. G., Nefiodov A. V., Sheil D., Nobre A. D., Shearman P., Li B.-L. Tellus A: Dynamic Meteorology and Oceanography. 2017, vol. 69 (1), pp. 1272752. DOI 10.1080/16000870.2016.1272752.

184. Hill S. A. Current Climate Change Reports. 2019, vol. 5 (3), pp. 160-171. DOI 10.1007/s40641-019-00137-8.

185. Arruda D. M., Schaefer C. E. G. R., Fonseca R. S., Solar R. R. C., Fernandes-Filho E. I. Global Ecology and Biogeography. 2018, vol. 27 (1), pp. 47-56. DOI 10.1111/geb.12646.

186. Ivory S. J., Russell J. Quaternary Science Reviews. 2016, vol. $148, \quad$ pp. $101-114$. DOI 10.1016/j.quascirev.2016.07.015.

187. Gill J. L., Williams J. W., Jackson S. T., Lininger K. B., Robinson G. S. Science. 2009, vol. 326 (5956), pp. 1100-1103. DOI 10.1126/science.1179504.

188. Gill J. L., Williams J. W., Jackson S. T., Donnelly J. P., Schellinger G. C. Quaternary Science Reviews. 2012, vol. 34, pp. 66-80. DOI 10.1016/j.quascirev.2011.12.008.

189. Doughty C. E., Wolf A., Field C. B. Geophysical Research Letters. 2010, vol. 37 (15), p. L15703. DOI 10.1029/2010g1043985.

190. Hoffmann W. A., Geiger E. L., Gotsch S. G., Rossatto D. R., Silva L. C. R., Lau O. L., Haridasan M., Franco A. C. Ecology Letters. 2012, vol. 15 (7), pp. 759-768. DOI 10.1111/j.1461-0248.2012.01789.x.

191. Sankaran M., Hanan N. P., Scholes R. J., Ratnam J., Augustine D. J., Cade B. S., Gignoux J., Higgins S. I., Le Roux X., Ludwig F., Ardo J., Banyikwa F., Bronn A., Bucini G., Caylor K. K., Coughenour M. B., Diouf A., Ekaya W., Feral C. J., February E. C., Frost P. G. H., Hiernaux P., Hrabar H., Metzger K. L., Prins H. H. T., Ringrose S., Sea W., Tews J., Worden J., Zambatis N. Nature. 2005, vol. 438 (7069), pp. 846-849. DOI 10.1038/nature04070.

192. Pausas J. G., Bond W. J. Trends in Plant Science. 2020, vol. 25 (3), pp. $250-263$. DOI 10.1016/j.tplants.2019.11.003

193. Wilcox B. P., Birt A., Fuhlendorf S. D., Archer S. R. Current Opinion in Environmental Sustainability. 2018, vol. 32, pp. 46-52. DOI 10.1016/j.cosust.2018.04.005.

194. Bond W. J., Woodward F. I., Midgley G. F. New Phytologist. 2005, vol. 165 (2), pp. $525-537$. DOI 10.1111/j.1469-8137.2004.01252.x.

195. Archibald S., Hempson G. P., Lehmann C. New Phytologist. 2019, vol. 224 (4), pp. 1490-1503. DOI 10.1111/nph.15986.

196. Midgley J. J. Australian Journal of Botany. 2013, vol. 61 (2), pp. 102-106. DOI 10.1071/BT12289.

197. Mutch R. W. Ecology. 1970, vol. 51 (6), pp. 1046-1051. DOI 10.2307/1933631.

198. Snyder J. R. Oikos. 1984, pp. 404-405.

199. Gagnon P. R., Passmore H. A., Platt W. J., Myers J. A., Paine C. E. T., Harms K. E. Ecology. 2010, vol. 91 (12), pp. 3481-3486. DOI 10.1890/10-0291.1.

200. Schertzer E., Staver A. C. Journal of the Royal Society Interface. 2018, vol. 15 (147), p. 20180444. DOI 10.1098/rsif.2018.0444.

201. Uyehara I. K., Pacala S. W. Theoretical Ecology. 2018, vol. 11 (3), pp. 291-303. DOI 10.1007/s12080-018-0366-3.

202. Pausas J. G. Journal of Functional Ecology. 2015, vol. 29 (3), pp. 315-327. DOI 10.1111/1365-2435.12372.

203. Pellegrini A. F. A., Anderegg W. R. L., Paine C. E. T., Hoffmann W. A., Kartzinel T., Rabin S. S., Sheil D., Franco A. C., Pacala S. W. Ecology Letters. 2017, vol. 20 (3), pp. 307-316. DOI 10.1111/ele.12725.

204. Bond W. J., Midgley G. F. Global Change Biology. 2000, vol. 6 (8), pp. 865-869. DOI 10.1046/j.13652486.2000.00365.x.

205. Stevens N., Archibald S. A., Bond W. J. Frontiers in Ecology and Evolution. 2018, vol. 6, pp. 137. DOI 10.3389/fevo.2018.00137.

206. Archibald S., Roy D. P., van Wilgen B. W., Scholes R. J. Global Change Biology. 2009, vol. 15 (3), pp. $613-630$. DOI 10.1111/j.1365-2486.2008.01754.x.

207. Eggeling W. J. Journal of Ecology. 1947, vol. 34 (1), pp. 20-87. DOI 10.2307/2256760.

208. Sheil D. Plant Ecology. 2001, vol. 155 (2), pp. 183-199. DOI 10.1023/A:1013243411819.

209. Van Nieuwstadt M. G. L., Sheil D. Journal of Ecology. 2005, vol. 93 (1), pp. 191-201. DOI 10.1111/j.13652745.2004.00954.x

210. Cochrane M. A. Nature. 2003, vol. 421 (6926), pp. 913-919. DOI 10.1038/nature01437. 
211. Brookfield H., Potter L., Byron Y. In Place of the Forest: Environmental and Socio-economic Transformations in Borneo and the Eastern Malay Peninsula. Tokyo, Japan: United Nations University Press, 1995, 310 p.

212. Goldammer J. G., Seibert B. Naturwissenschaften [ ]. 1989, vol. 76 (11), pp. 518-520. DOI 10.1007/BF00374124.

213. Barker G., Hunt C., Barton H., Gosden C., Jones S., Lloyd-Smith L., Farr L., Nyirí B., O'Donnell S. Quaternary International. 2017, vol. 448, pp. 44-61. DOI 10.1016/j.quaint.2016.08.018.

214. Sheil D., Basuki I., German L., Kuyper T. W., Limberg G., Puri R. K., Sellato B., Van Noordwijk M., Wollenberg E. Forests. 2012, vol. 3 (2), pp. 207-229. DOI 10.3390/f3020207.

215. Hammond D. S., H. ter Steege, van der Borg K. Biotropica. 2007, vol. 39 (2), pp. 153-160. DOI 10.1111/j.17447429.2006.00257.x.

216. Bush M. B., Silman M. R., de Toledo M. B., Listopad C., Gosling W. D., Williams C., de Oliveira P. E., Krisel C. Philosophical Transactions of the Royal Society B. 2007, vol. 362 (1478), pp. 209-218. DOI 10.1098/rstb.2006.1980.

217. Cordeiro R. C., Turcq B., Moreira L. S., R. de A. R. Rodrigues, F. F. Lamego Simões Filho, Martins G. S., Santos A. B., Barbosa M., M. C. Guilles da Conceição, R. da C. Rodrigues, Evangelista H., Moreira-Turcq P., Penido Y. P., Sifeddine A., Seoane J. C. S. Palaeogeography, Palaeoclimatology, Palaeoecology. 2014, vol. 415, pp. 137-151. DOI 10.1016/j.palaeo.2014.07.020.

218. Makarieva A. M., Gorshkov V. G. International Journal of Water. 2010, vol. 5 (4), pp. 365-385. DOI 10.1504/ IJW.2010.038729.

219. Sheil D., Murdiyarso D. Bioscience. 2009, vol. 59 (4), pp. 341-347. DOI 10.1525/bio.2009.59.4.12.

220. Laurance W. F., Williamson G. B. Conservation Biology. 2001, vol. 15 (6), pp. 1529-1535. DOI 10.1046/j.1523-1739.2001.01093.x.

221. Edwards H. G. M. Proceedings of the Royal Society A: Mathematical, Physical and Engineering Sciences. 2014, vol. 372 (2030), pp. 20140206. DOI 10.1098/rsta.2014.0206.

222. Restuccia F., Huang X., Rein G. Fire Safety Journal. 2017, vol. 91, pp. 828-834. DOI 10.1016/j.firesaf.2017.03.052.

223. Pechony O., Shindell D. T. Proceedings of the National Academy of Sciences of the United States of America. 2010, vol. 107 (45), pp. 19167-19170. DOI 10.1073/pnas.1003669107.

224. Flannigan M. D., Krawchuk M. A., de Groot W. J., Wotton B. M., Gowman L. M. J International Journal of Wildland Fire. 2009, vol. 18 (5), pp. 483-507. DOI 10.1071/WF08187.

225. Singh R. V. K. Procedia Engineering. 2013, vol. 62, pp. 78-90. DOI 10.1016/j.proeng.2013.08.046.

226. Fredriksson G. Communities in flames: Proceedings of an international conference on community involvement in fire management. Bangkok, Thailand: FAO and FireFight SE Asia, 2002.

227. Whitehouse A. E., Mulyana A. A. S. International Journal of Coal Geology. 2004, vol. 59 (1-2), pp. 91-97. DOI 10.1016/j.coal.2003.08.010.

228. Johnson C. N., Prior L. D., Archibald S., Poulos H. M., Barton A. M., Williamson G. J., Bowman D. M. J. S. Philosophical Transactions of the Royal Society B: Biological Sciences. 2018, vol. 373 (1761), p. 20170443. DOI 10.1098/rstb.2017.0443.

229. Van Langevelde F., Van De Vijver C. A. D. M., Kumar L., Van De Koppel J., De Ridder N., Van Andel J., Skidmore A. K., Hearne J. W., Stroosnijder L., Bond W. J., Prins H. H. T., Rietkerk M. Ecology. 2003, vol. 84 (2), pp. 337-350. DOI 10.1890/0012-9658(2003)084[0337:EOFAHO]2.0.CO;2.

230. The Ecology of Browsing and Grazing II. Ed. by I. J. Gordon, H. H. T. Prinss. Springer, 2019, 451 p.

231. Foster C. N., Banks S. C., Cary G. J., Johnson C. N., Lindenmayer D. B., Valentine L. E. Trends in Ecology \& Evolution. 2020, vol. 35 (4), pp. 346-356. DOI 10.1016/j.tree.2020.01.002.

232. Ssekuubwa E., Loe L. E., Sheil D., Tweheyo M., Moe S. R. Restoration Ecology. 2018, vol. 26 (4), pp. $720-728$. DOI $10.1111 /$ rec. 12629 .

233. Ickes K., DeWalt S. J., Appanah S. Journal of Tropical Ecology. 2001, vol. 17 (2), pp. $191-206$. DOI 10.1017/S0266467401001134.

234. Barrios-Garcia M. N., Ballari S. A. Biological Invasions. 2012, vol. 14 (11), pp. $2283-2300$. DOI 10.1007/s10530-012-0229-6.

235. Curran L. M., Caniago I., Paoli G. D., Astianti D., Kusneti M., Leighton M., Nirarita C. E., Haeruman H. Science. 1999, vol. 286 (5447), pp. 2184-2188. DOI 10.1126/science.286.5447.2184.

236. Moe S. R., Rutina L. P., Hytteborn H., J. T. Du Toit Journal of Applied Ecology. 2009, vol. 46 (1), pp. $223-230$. DOI 10.1111/j.1365-2664.2008.01595.x.

237. Bonta M., Gosford R., Eussen D., Ferguson N., Loveless E., Witwer M. Journal of Ethnobiology. 2017, vol. 37 (4), pp. 700-719. DOI 10.2993/ 0278-0771-37.4.700.

238. Coghlan A. New Scientist. 2018, vol. 237 (4).

239. Augustine D. J., McNaughton S. J. Journal of Applied Ecology. 2004, vol. 41 (1), pp. $45-58$. DOI 10.1111/j.1365-2664.2004.00864.x.

240. Staver A. C., Bond W. J., Stock W. D., van Rensburg S. J., Waldram M. S. Ecological Applications. 2009, vol. 19 (7), pp. 1909-1919. DOI 10.1890/08-1907.1.

241. LaMalfa E. M., Kimuyu D. M., Sensenig R. L., Young T. P., Riginos C., Veblen K. E. Journal of Ecology. 2019, vol. 107 (5), pp. 2493-2502. DOI 10.1111/1365-2745.13186. 
242. Hempson G. P., Archibald S., Bond W. J., Ellis R. P., Grant C. C., Kruger F. J., Kruger L. M., Moxley C., OwenSmith N., Peel M. J. S., Vickers K. J. Biological Reviews. 2015, vol. 90 (3), pp. 979-994. DOI 10.1111/brv.12145.

243. Holdo R. M., Sinclair A. R. E., Dobson A. P., Metzger K. L., Bolker B. M., Ritchie M. E., Holt R. D. PLOS Biology. 2009, vol. 7 (9), p. e1000210. DOI 10.1371/journal.pbio.1000210.

244. Prins H. H. T., van der Jeugd H. P. Journal of Ecology. 1993, pp. 305-314. DOI 10.2307/2261500.

245. Bowman D. M. J. S., Murphy B. P., McMahon C. R. Journal of Biogeography. 2010, vol. 37 (3), pp. $499-505$. DOI 10.1111/j.1365-2699.2009.02206.x.

246. Murphy B. P., Bowman D. M. J. S. Ecology Letters. 2012, vol. 15 (7), pp. 748-758. DOI 10.1111/j.14610248.2012.01771.x.

247. Archibald S., Bond W. J., Hoffmann W., Lehmann C., Staver C., Stevens N. Savanna and Woody Plants Large Herbivores. 2019, pp. 1-24. DOI 10.1002/9781119081111.ch1.

248. Sheil D. Plant Ecology. 1999, vol. 140 (1), pp. 117-127. DOI 10.1023/A:1009729108668.

249. Enquist B. J., Abraham A. J., Harfoot M. B. J., Malhi Y., Doughty C. E. Nature Communications. 2020 , vol. 11 (1), p. 699. DOI 10.1038/s41467-020-14369-y.

250. Haynes G. Geomorphology. 2012, vol. 157-158, pp. 99-107. DOI 10.1016/j.geomorph.2011.04.045.

251. Arsenault R., Owen-Smith N. Oikos. 2002, vol. 97 (3), pp. 313-318. DOI 10.1034/j.1600-0706.2002.970301.x.

252. Janzen D. H., Martin P. S. Science. 1982, vol. 215 (4528), pp. 19-27. DOI 10.1126/science.215.4528.19.

253. Bunney K., Robertson M., Bond W. Biological Journal of the Linnean Society. 2019, vol. 128 (4), pp. $1039-1051$. DOI 10.1093/biolinnean/blz109.

254. Hawthorne W. D., Parren M. P. E. Journal of Tropical Ecology. 2000, vol. 16 (1), pp. $133-150$. DOI $10.1017 / \mathrm{S} 0266467400001310$.

255. Campos-Arceiz A., Blake S. Acta Oecologica. 2011 , vol. 37 (6), pp. 542-553. DOI 10.1016/j.actao.2011.01.014.

256. Ivanova N. V., Smirnov V. E., Khanina L. G., Bobrovsky M. V., Shashkov M. P. Biology Bulletin. 2018, vol. 45, pp. 100-109. DOI 10.1134/ S1062359018010053.

257. Smirnova O. V., Gerasinka A. P., Aleynikov A. A. Russian Journal of Ecosystem Ecology. 2018, vol. 3 (3). DOI 10.21685/2500-0578-2018-3-1.

258. Scheffer M., Holmgren M., Brovkin V., Claussen M. Global Change Biology. 2005, vol. 11 (7), pp. $1003-1012$. DOI 10.1111/j.1365-2486.2005.00962.x.

259. Lenton T. M., Rockström J., Gaffney O., Rahmstorf S., Richardson K., Steffen W., Schellnhuber H. J. Nature. 2019, vol. 575, pp. 592-595. DOI 10.1038/d41586-019-03595-0.

260. Brook B. W., Ellis E. C., Perring M. P., Mackay A. W., Blomqvist L. Trends in Ecology \& Evolution. 2013, vol. 28 (7), pp. 396-401. DOI 10.1016/j.tree.2013.01.016.

261. Bird M. I., Hutley L. B., Lawes M. J., Lloyd J., Luly J. G., Ridd P. V., Roberts R. G., Ulm S., Wurster C. M. Journal of Quaternary Science. 2013, vol. 28 (5), pp. 439-452. DOI 10.1002/jqs.2639.

262. Miller G. H., Fogel M. L., Magee J. W., Gagan M. K. Quaternary Science Reviews. 2016, vol. 151, pp. $27-57$. DOI 10.1016/ j.quascirev.2016.08.009.

263. Lovejoy T. E., Nobre C. Science Advances. 2018, vol. 4 (2), p. eaat2340. DOI 10.1126/sciadv.aat2340.

264. Walker X. J., Baltzer J. L., Cumming S. G., Day N. J., Ebert C., Goetz S., Johnstone J. F., Potter S., Rogers B. M., Schuur E. A. G., Turetsky M. R., Mack M. C. Nature. 2019, vol. 572 (7770), pp. $520-523$. DOI 10.1038/s41586-019-1474-y.

265. Acanakwo E. F., Okullo P., Sheil D., Moe S. R. Journal of Vegetation Science. 2018, vol. 29 (6), pp. 989-998. DOI 10.1111/jvs.12682. 